\title{
Fuel Fabrication Facility Study for FCF HALEU
}

D. C. Crawford, C. E. Baily, C. R. Clark, R. S. Fielding, S. C. Marschman

March 2019

The INL is a

U.S. Department of Energy

National Laboratory

operated by

Battelle Energy Alliance

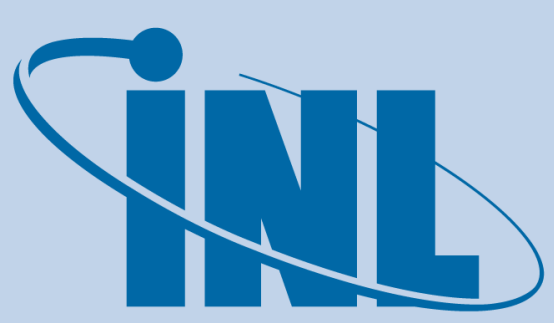

Idaho National Laboratory

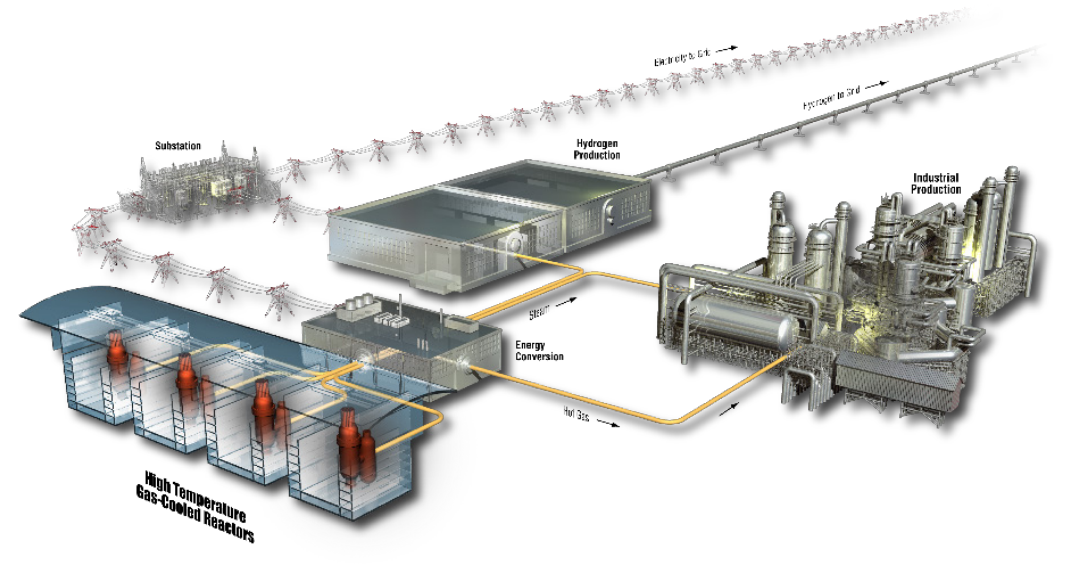




\section{DISCLAIMER}

This information was prepared as an account of work sponsored by an agency of the U.S. Government. Neither the U.S. Government nor any agency thereof, nor any of their employees, makes any warranty, expressed or implied, or assumes any legal liability or responsibility for the accuracy, completeness, or usefulness, of any information, apparatus, product, or process disclosed, or represents that its use would not infringe privately owned rights. References herein to any specific commercial product, process, or service by trade name, trade mark, manufacturer, or otherwise, does not necessarily constitute or imply its endorsement, recommendation, or favoring by the U.S. Government or any agency thereof. The views and opinions of authors expressed herein do not necessarily state or reflect those of the U.S. Government or any agency thereof. 
INL/EXT-19-52614

Revision 0

\title{
Fuel Fabrication Facility Study for FCF HALEU
}

\author{
D. C. Crawford, C. E. Baily, C. R. Clark,
}

R. S. Fielding, S. C. Marschman

March 2019

Idaho National Laboratory
INL ART Program
Idaho Falls, Idaho 83415

http://www.inl.gov

Prepared for the

U.S. Department of Energy

Office of Nuclear Energy

Under DOE Idaho Operations Office

Contract DE-AC07-05ID14517 



\section{INL ART Program \\ Fuel Fabrication Facility Study for FCF HALEU \\ INL/EXT-19-52614 \\ Revision 0 \\ March 2019}

Author:

$D C$ Crawtord

Douglas C. Crawford

March 27, 2019

MFC Chief Scientist

Date

Technical Reviewer: (Confirmation of mathematical accuracy, and correctness of data and appropriateness of assumptions.)

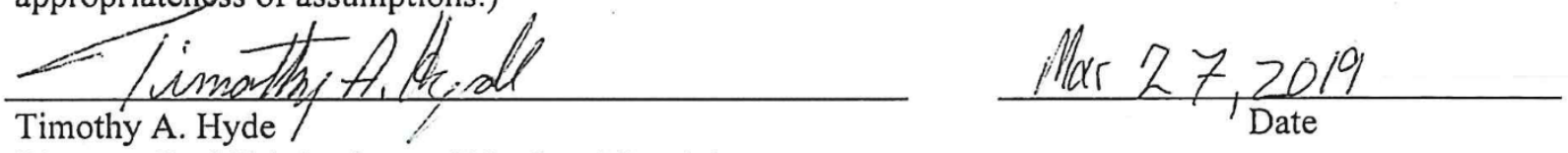

Director, Fuel Fabrication and Nuclear Materials

Project Management Reviewer: (Confirmation that cost estimates and described scope are adequate for the intended purpose and properly represented.)

Brady J. Orchard

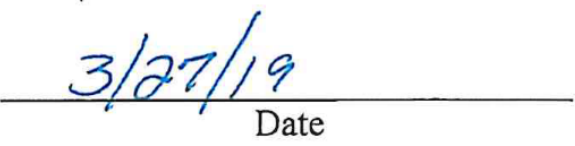

Director, MFC Projects

\section{Approved by:}

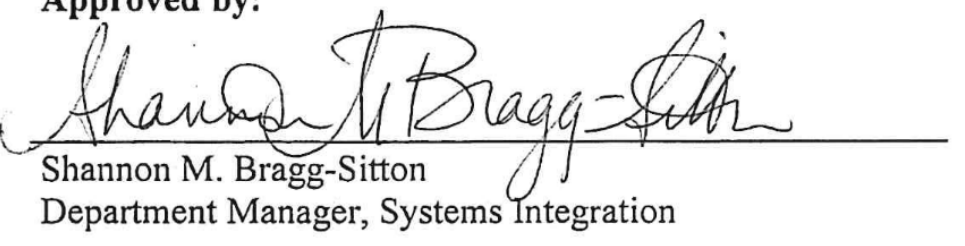

$\frac{3 / 29 / 2019}{\text { Date }}$
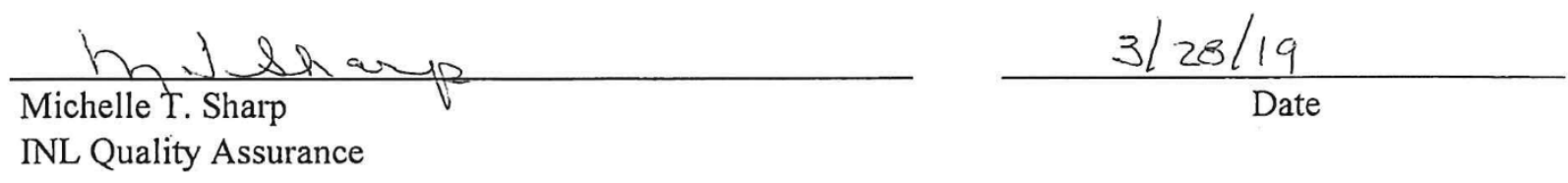


\section{REVISION LOG}

\begin{tabular}{|c|c|c|c|}
\hline Rev. & Date & Affected Pages & Revision Description \\
\hline 0 & $03 / 29 / 2019$ & All & New document. \\
\hline & & & \\
\hline & & & \\
\hline & & & \\
\hline & & & \\
\hline & & & \\
\hline & & & \\
\hline & & & \\
\hline & & & \\
\hline & & & \\
\hline & & & \\
\hline & & & \\
\hline & & & \\
\hline & & & \\
\hline & & & \\
\hline & & & \\
\hline & & & \\
\hline & & & \\
\hline
\end{tabular}





\section{ABSTRACT}

Nuclear energy technology developers seek to bring to market new advanced-reactor designs and new light-water reactor fuel designs, many of which would deploy fuel made from uranium with ${ }^{235} \mathrm{U}$ enrichment ranging from $5 \%$ to $19.75 \%$. There is currently no commercial supply of uranium in this enrichment range, which is higher than that used in today's light-water reactors, but still lower than the safeguards limit of $20 \%{ }^{235} \mathrm{U}$. This limitation is a barrier to demonstration of these new nuclear energy technologies. As a means of addressing this near-term need, Department of Energy (DOE) and Idaho National Laboratory (INL) have considered how the high-assay low-enriched uranium (HALEU) product from sodium-bonded spent-fuel treatment in the INL Fuel Conditioning Facility (FCF), located at the Materials and Fuels Complex (MFC), might be fabricated into some of the new fuel designs.

The evaluation presented in this report addresses the potential establishment of two types of fuel-fabrication capabilities at INL, represented generically as a ceramic/intermetallic-type (or pellet-type) fuel-fabrication line and a metallic fuel-fabrication line. Because FCF HALEU feedstock contains residual transuranic contaminations and a relatively small amount of residual fission products, fuel fabrication using that material must be performed inside of engineered confinement barriers, such as gloveboxes, filled with inert gas for most of the fuel types considered. The throughput rate of the fabrication lines envisioned is 2.5 metric tons of HALEU fuel per year, which is judged to be sufficiently representative of engineering scale (i.e., production rates 1 to 2 orders of magnitude lower than is typical of commercial fuel fabrication facilities). Space in three existing buildings was identified for consideration in this study of preconceptual equipment layouts. The scope and nature of the work needed to prepare each of the three buildings for each type of fuel fabrication was identified (though not in engineering detail), and three-dimensional models of envisioned fabrication equipment were laid out in each of the buildings to assess adequacy of space.

The study concluded that either type of fuel fabrication line can feasibly be installed and operated in any of the three buildings. However, each of the three buildings presents different challenges due to accommodating current missions that would need to be relocated, necessary decontamination and decommissioning work to free space for fuel fabrication, or complications of accessibility. Rough order-of-magnitude (ROM) cost estimates for preparing the buildings begin at $\$ 10 \mathrm{M}(-20 \% /+50 \%)$ and would increase with complexity of building modifications. The cost of fabrication equipment and gloveboxes is roughly estimated to be $\$ 22.5 \mathrm{M}(-20 \% /+50 \%)$ for a metallic fuel-fabrication line and $\$ 28 \mathrm{M}(-20 \% /+50 \%)$ for a ceramic/intermetallic fuel-fabrication line.

Nominal operating costs are estimated to increase to \$7M per year (in 2019 dollars), as the operating crew is being assembled and trained. 


\section{CONTENTS}

ABSTRACT vii

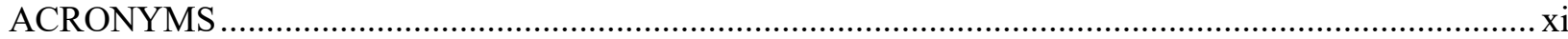

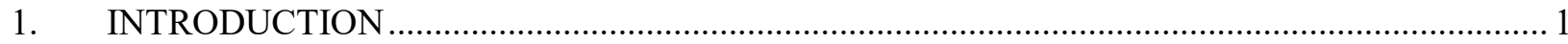

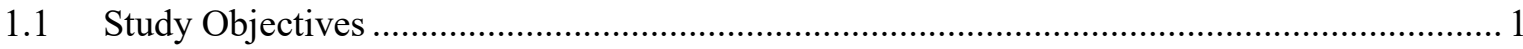

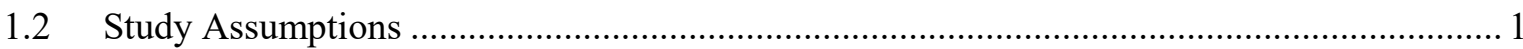

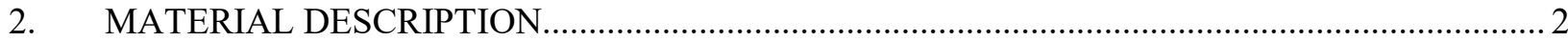

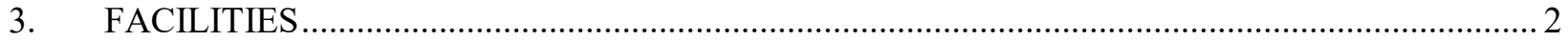

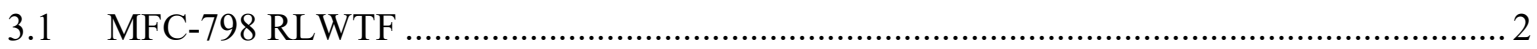

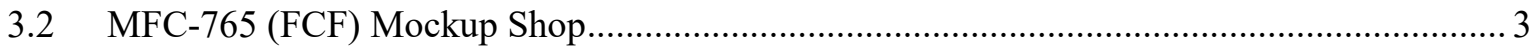

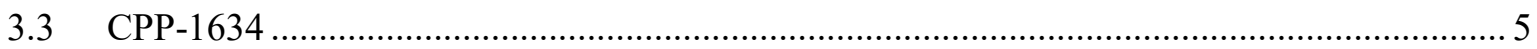

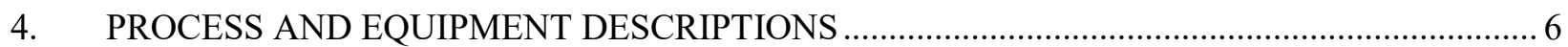

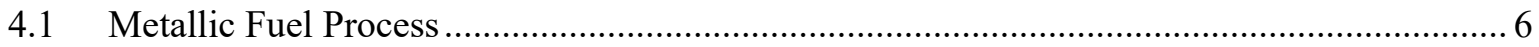

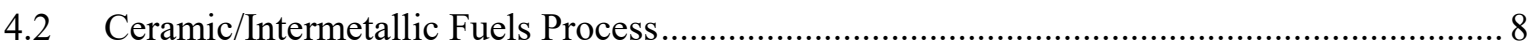

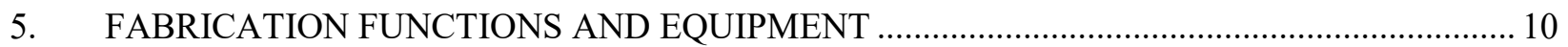

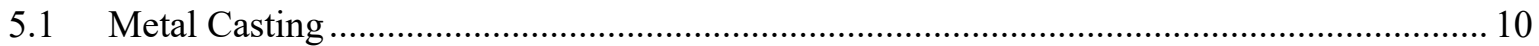

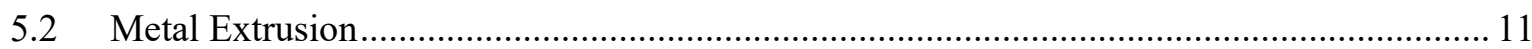

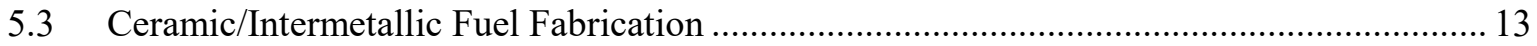

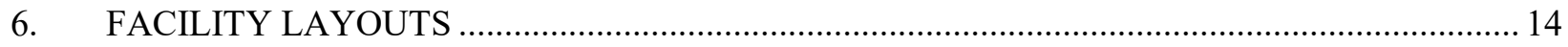

6.1 MFC-798 (Radioactive Liquid Waste Treatment Facility (or RLWTF).............................. 14

6.1.1 Ceramic/Intermetallic Fuel Fabrication ................................................................ 14

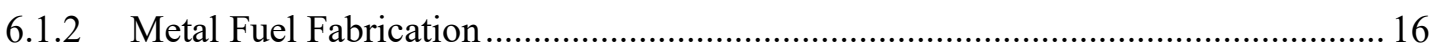

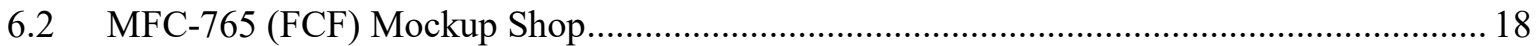

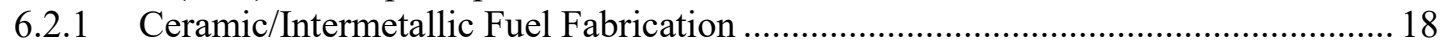

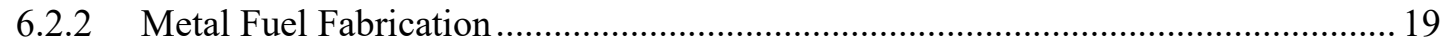

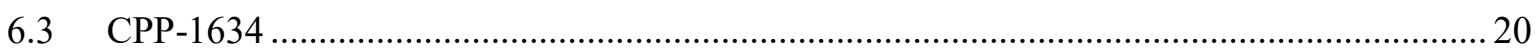

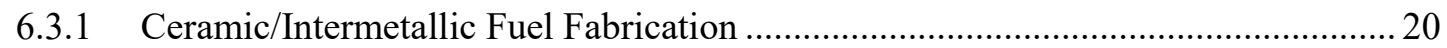

6.3.2 Metal Fuel Fabrication ................................................................................... 21

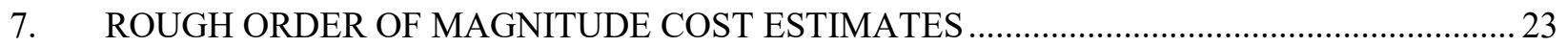

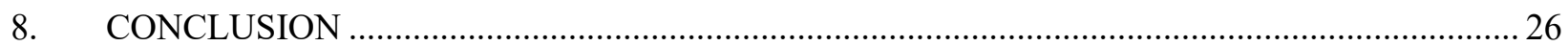

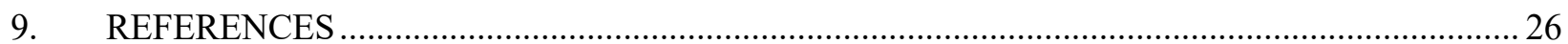




\section{FIGURES}

Figure 1. Building MFC-798, the Radioactive Liquid Waste Treatment Facility, a two-story, concrete-masonry block building, located in north central MFC.

Figure 2. Photo showing the north side of MFC-765, the Fuel Conditioning Facility (FCF), located in the center of MFC. The FCF Mockup Shop area is located in north portion of the high bay shown in the foreground.

Figure 3. Building CPP-1634, located on the western edge of the Idaho Nuclear Technology and Engineering Center. The building is constructed as a large, high-bay space.............................. 5

Figure 4. Second floor of the RLWTF where ceramic/intermetallic fuel production would begin............ 15

Figure 5. First floor of the RLWTF where ceramic/intermetallic fuel work would be completed............ 16

Figure 6. Metal fuel production begins on the first floor of RLWTF. Two casting furnaces are

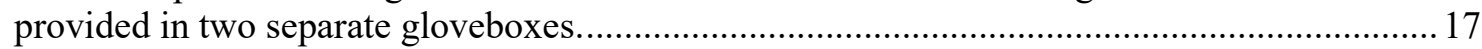

Figure 7. RLWTF second floor layout for metal fuel production........................................................... 18

Figure 8. Ceramic/intermetallic fuel production line shown in the FCF Mockup Shop location.

Figure 9. Metal fuel casting line shown in the FCF Mockup Shop. The two casting gloveboxes could be replaced by a metal-extrusion press as needed. The transition gloveboxes

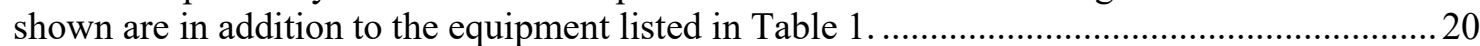

Figure 10. Ceramic/intermetallic fuel production line installed in CPP-1634 ........................................ 21

Figure 11. Metal-fuel casting line installed in the CPP-1634 building. ...............................................22

\section{TABLES}

Table 1. Glovebox requirements for casting and producing metal fuels. ............................................... 10

Table 2. Glovebox requirements for extruding and producing metal fuels. ............................................ 12

Table 3. Glovebox requirements for ceramic/intermetallic fuel production. .......................................... 13

Table 4. ROM cost estimates $(-20 \% /+50 \%$ for values indicated) to prepare selected INL facilities for engineering-scale HALEU fuel fabrication (see Section 7 text for explanation)..................24

Table 5. Summary of ROM cost estimates $(-20 \% /+50 \%)$ for equipment design, procurement, and installation into INL facilities for engineering-scale HALEU fuel fabrication (see Section 7 text for explanation)

Table 6. Detailed ROM cost estimates $(-20 \% /+50 \%)$ for equipment procurement for engineering-scale HALEU fuel fabrication (see Section 7 text for explanation)

Table 7. ROM cost estimates (with notional schedule) for operations to startup and implement engineering-scale HALEU fuel fabrication (see Section 7 text for explanation). 26 


\section{ACRONYMS}

$\begin{array}{ll}\text { ART } & \text { Advanced Reactor Technologies } \\ \text { DOE } & \text { Department of Energy } \\ \text { EBR-II } & \text { Experimental Breeder Reactor-II } \\ \text { FCF } & \text { Fuel Conditioning Facility } \\ \text { HALEU } & \text { high-assay low-enriched uranium } \\ \text { HC-2 } & \text { Hazard Category 2 } \\ \text { HEPA } & \text { high-efficiency particulate air } \\ \text { HFEF } & \text { Hot Fuel Examination Facility } \\ \text { ICPP } & \text { Idaho Chemical Processing Plant } \\ \text { INL } & \text { Idaho National Laboratory } \\ \text { INTEC } & \text { Idaho Nuclear Technology and Engineering Center } \\ \text { LTHC3 } & \text { Less Than Hazard Category 3 } \\ \text { MFC } & \text { Materials and Fuels Complex } \\ \text { MTHM/yr } & \text { metric tons of heavy metal per year } \\ \text { RLWTF } & \text { Radioactive Liquid Waste Treatment Facility } \\ \text { ROM } & \text { rough order-of-magnitude } \\ \text { TRU } & \text { transuranic } \\ \text { U.S. } & \text { United States }\end{array}$




\section{Fuel Fabrication Facility Study for FCF HALEU \\ 1. INTRODUCTION}

Private-sector nuclear technology developers have responded to market needs for economic, low-carbon energy with initiatives to design, license, and sell nuclear reactors of advanced design. ${ }^{1,2}$ This activity and investment in new nuclear energy technologies in the United States (U.S.) by the private sector has motivated interest in uranium fuel with enrichments ranging from 5 to $20 \%{ }^{235} \mathrm{U}$ (termed high-assay low-enriched uranium [HALEU]). Currently, there is no commercial supply of HALEU in any form: $\mathrm{UF}_{6}, \mathrm{U}_{3} \mathrm{O}_{8}, \mathrm{UO}_{2}$, $\mathrm{U}$ metal, or finished fuel. Because nuclear technology developers seek to accelerate their path to market, they have requested that the Department of Energy (DOE) provide HALEU from U.S. Government-owned stockpiles for early demonstration purposes in first cores of microreactors or lead test rods and assemblies for use in commercial light-water reactors. ${ }^{3}$ As one means to meet part of this need, DOE and Idaho National Laboratory (INL) are evaluating how the HALEU product from sodium-bonded spent-fuel treatment in the INL Fuel Conditioning Facility (FCF), located at the Materials and Fuels Complex (MFC), might be made available and fabricated into some of the new fuel designs. This effort is challenged by the following:

- The fuel designs and fabrication processes are not yet specified, although they can be envisioned based on what is known about private-developers' designs and fabrication of traditional fuel

- The FCF HALEU product will contain some residual contaminants that emit radiation, although an effort is underway to reduce those radiation levels to allow contact handling of the material, and will have at least trace or suspect quantities of transuranic (TRU) contamination, requiring that the material be handled with containment, such as in gloveboxes

- There is no capability currently at INL, nor in the United States, for engineering-scale HALEU fuel fabrication (approximately 0.5 to 5 metric tons of heavy metal per year [MTHM/yr]), and no INL facilities are currently able to accommodate installation of a fabrication line.

\subsection{Study Objectives}

Objectives of this study are:

- Determine whether INL facilities can suitably house engineering-scale HALEU fuel fabrication for multiple types or designs of fuel

- Determine rough order-of-magnitude (ROM) costs to prepare facilities for the types of fabrication anticipated.

\subsection{Study Assumptions}

This study makes the following assumptions:

- The ongoing FCF decontamination study, also funded by the U.S. DOE, will determine a process that will repeatedly and reliably produce HALEU material with radiation fields low enough to allow contact handling in gloveboxes (even if the gloveboxes require some shielding or processes require simple automation to reduce worker radiation dose).

- Fabrication of two fuel types, generally ceramic and metal, is considered, with distinctions of specific fuel types assumed as needed to ensure more bounding aspects of accommodating some fuel designs are not overlooked. (In other words, this study does not formally address distinctions of fabricating specific fuel designs beyond general distinctions between fabricating ceramic fuel by casting particulate feed and extruding metal fuel).

- The desired fabrication rate for each fabrication line will be $2.5 \mathrm{MTHM} / \mathrm{yr}$ or less. 
- Operation at the assumed throughput rate will require uranium material in the building in quantities sufficient to require a Hazard Category 2 (HC-2) classification, although security requirements will be relatively modest due to ${ }^{235} \mathrm{U}$ enrichment maintained at less than $20 \%$ (Attractiveness Level $\mathrm{E}$ material, per the DOE standard for nuclear material control and accountability) ${ }^{4}$.

- The feedstock material used to supply each fuel fabrication line will be 3-kg metal regulus ingots.

- Any of the buildings selected for fuel fabrication will need new ventilation ductwork specific to the equipment being installed and, likely, new filter housings, fans, and a monitored stack.

- There is no a priori reason to place one type of fuel fabrication in one candidate building over the others. In other words, this study begins with the assumption that either the metal or ceramic fabrication lines could be installed into any of the three buildings considered.

- Facility preparation for installing equipment (i.e., gloveboxes and general-use processing equipment) and ventilation can be addressed and funded separately from an effort to install equipment for a specific fuel design (primarily to allow cost partitioning to accommodate different funding strategies).

- Layout of generic processes will be sufficiently indicative of floor space needed to support the current objective of identifying suitable facilities. To some degree, what is known about anticipated fabrication needs will inform this study, even if those needs are proprietary and cannot be stated. In other words, this study will look at generic processes, but will consider some specific examples to ensure needs are addressed to the extent possible.

\section{MATERIAL DESCRIPTION}

As stated in the assumptions, the feedstock form supplying each of the envisioned fabrication lines is assumed to be in the form of 3-kg metal ingots. Because the FCF decontamination study is ongoing, with only preliminary dose-rate measurements available and no detailed impurity analyses yet available, the specific impurities and dose rates to inform the facility design basis remain to be determined. However, the early result showing decontamination down to a 25 -mrem dose rate is promising.

\section{FACILITIES}

Three INL facility spaces have been identified for this study, based partly on potential apparent floor space and availability: MFC-798, Radioactive Liquid Waste Treatment Facility (RLWTF); FCF (MFC-765) Mockup Shop; and CPP-1634 (formerly, the Idaho Chemical Processing Plant [ICPP] Technology Development Facility). Other spaces at INL or other DOE sites might also be found suitable, but the scope was limited to these three spaces to provide early feedback on feasibility and cost range.

For the purpose of this study, it is sufficient to consider that the same equipment, gloveboxes, ventilation ducts and components, and monitored stack would be installed into any of the three buildings, with possible exceptions as noted in the facility summaries below.

\section{$3.1 \quad$ MFC-798 RLWTF}

RLWTF (Figure 1) was used to treat radioactive liquid wastes from the Hot Fuel Examination Facility (HFEF), FCF, and other facilities at MFC. RLWTF is no longer used for that purpose, although the piping, components, tanks, ventilation, control panels, and equipment remain in place. Attributes of and considerations for use of the RLWTF building (MFC-798) include the following:

- The building has no current or proposed mission.

- The building should be suitable for HC-2 operation, but that remains to be confirmed.

- Engineering opinion is that none of the current equipment within the building, except possibly the six high-efficiency particulate air (HEPA) filter housings, is useful for a fuel-fabrication mission. All 
equipment would need to be removed in a decontamination and decommissioning project to make space available for equipment and ventilation.

- Efficient use of the building would likely require minor reconfiguration to remove and relocate a staircase in the middle of the operating floor to another location, such as outside of the building.

- Security impacts to HALEU operations in RLWTF would be limited to the access control requirements for the facility. Other security functions do not impact HALEU operations and are covered under general MFC security requirements.

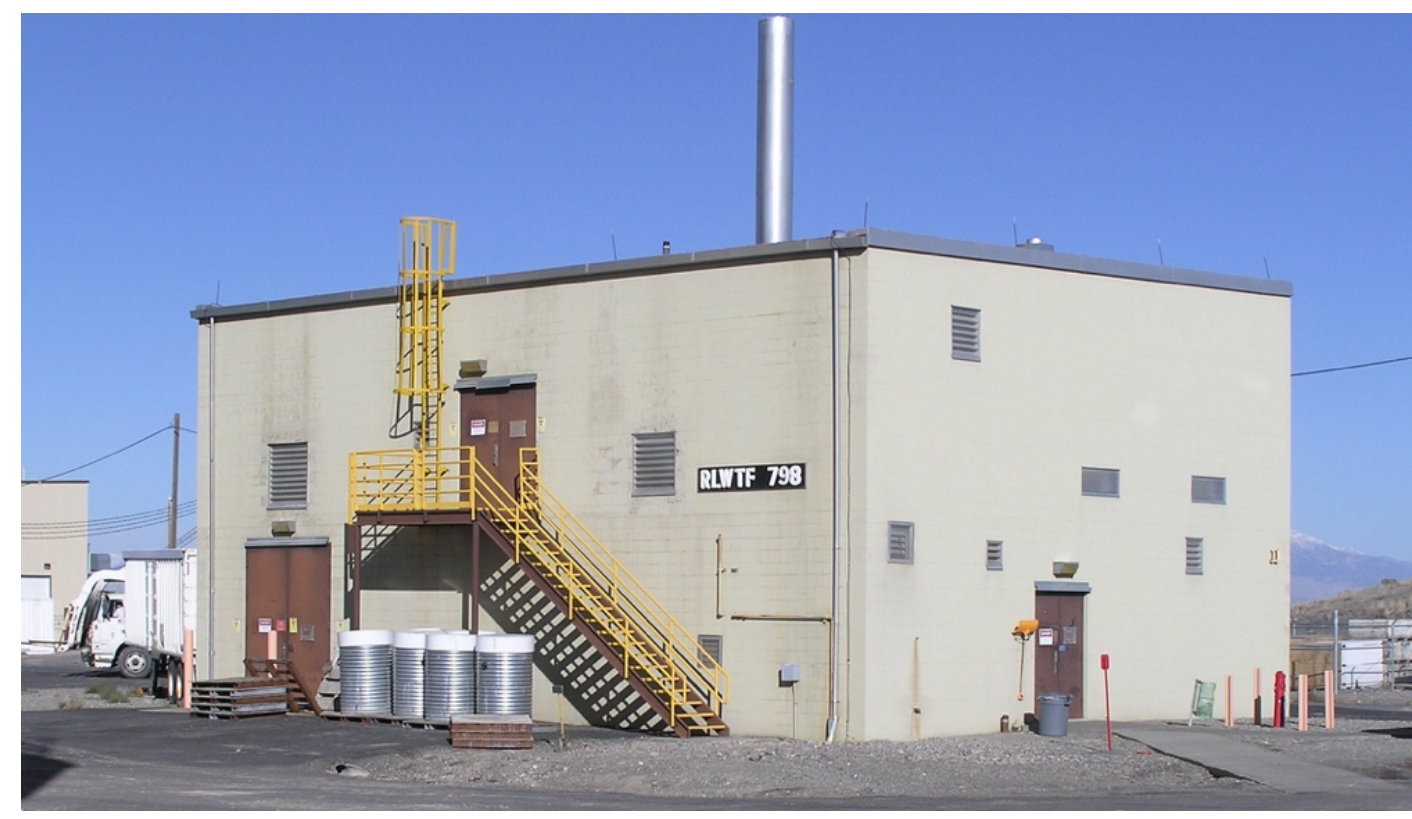

Figure 1. Building MFC-798, the Radioactive Liquid Waste Treatment Facility, a two-story, concrete-masonry block building, located in north central MFC.

\subsection{MFC-765 (FCF) Mockup Shop}

The FCF Mockup Shop area (see Figure 2) is accessible from the FCF operating floor and is used for testing and modifying equipment for remote operation prior to installation in a hot cell at FCF or HFEF. The area is somewhat undersized for the current needs of the mockup shop, which call for more space for large machines. The area includes $8-\mathrm{ft}$ and $30-\mathrm{ft}$ pits for mocking up equipment and operations that will access the storage or long-experiment pits in HFEF. The area sits under the FCF high bay, with sufficient overhead space to operate an overhead crane and overhead electromechanical manipulator of the type and elevation as those used in the FCF and HFEF hot cells. Attributes of and considerations for use of the FCF Mockup Shop include the following: 


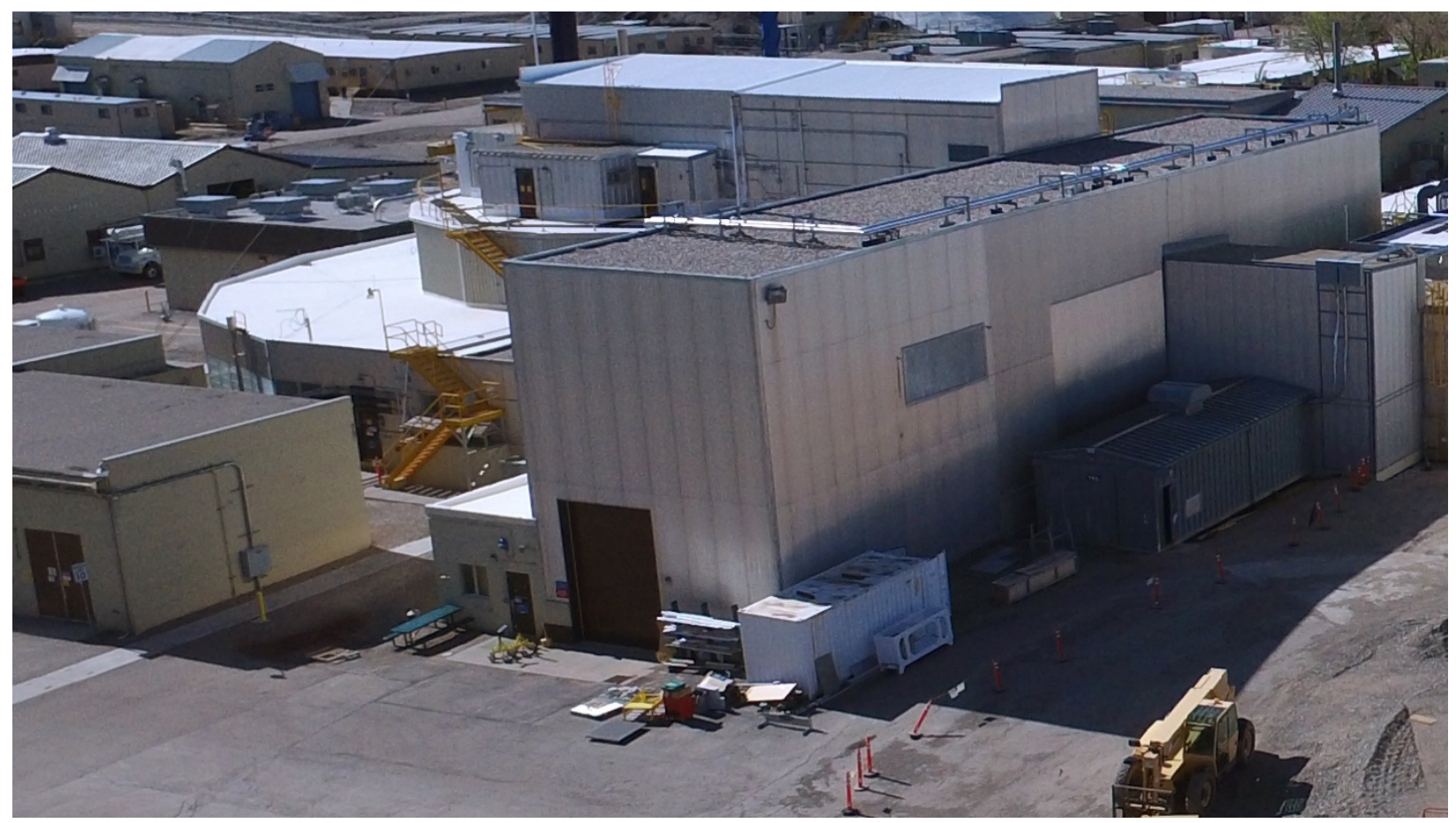

Figure 2. Photo showing the north side of MFC-765, the Fuel Conditioning Facility (FCF), located in the center of MFC. The FCF Mockup Shop area is located in north portion of the high bay shown in the foreground.

- The floor space, if cleared of all the current equipment, would likely be suitable for housing HALEU fuel fabrication. If the FCF subassembly wash station, adjacent to the former cask path to Experimental Breeder Reactor-II (EBR-II) and to the mockup shop, is decontaminated and decommissioned, and removed, then additional floor space could be incorporated.

- FCF is a HC-2 nuclear facility.

- Use of the mockup shop will require relocating the current mockup shop mission to a different, yet-unidentified space. That new space would require roughly the same footprint, overhead clearance for an overhead crane and electromechanical manipulator, and some means of mocking up equipment to be located in (or to otherwise access) the HFEF pits. Pit mockup need not be limited to floor pits, but could also be accomplished using elevated spaces and mezzanines. Any new mockup shop location must be within the MFC fence, preferably near FCF and HFEF. Potential spaces and buildings have been proposed and are being evaluated.

- Because the mockup shop is located under the same high-bay area as part of the FCF operating floor, enclosing a fuel -fabrication facility in its own large room might be necessary to ensure any contamination release remains confined to the fuel fabrication area. It is also likely that new, dedicated ventilation filter housings and fans would be needed. It is not clear whether ventilation exhaust could be routed through the existing FCF stack or a new dedicated stack would be needed.

- The impact of FCF security on the HALEU fuel-fabrication mission is not fully known at this time, but may require access control similar to other high-security facilities. HALEU is Attractiveness Level E material, and security requirements would be less restrictive than for higher attractiveness level materials. Other security functions do not impact HALEU operations and are covered under general FCF security requirements. 


\section{$3.3 \quad$ CPP-1634}

Building CPP-1634 is located at the Idaho Nuclear Technology and Engineering Center (INTEC), and was originally named the ICPP Technology Development Facility, and was "designed as a fluorinel dissolution development and support facility in the late 1980s. The building was constructed [a few years later] in approximately 1993 and was used to support venting and head space gas sampling of contact-handled and remote-handled transuranic (TRU) waste drums." ${ }^{5}$ The footprint is modest, but the height of the building is relatively great. At one time, the building had filtered ventilation with an exterior exhaust stack, but that ventilation system has since been removed. The building is currently used to store and maintain radioisotope power source casks and to train and qualify personnel in cask handling, but the building has no other installed equipment. Attributes of and considerations for use of Building CPP-1634 include the following:

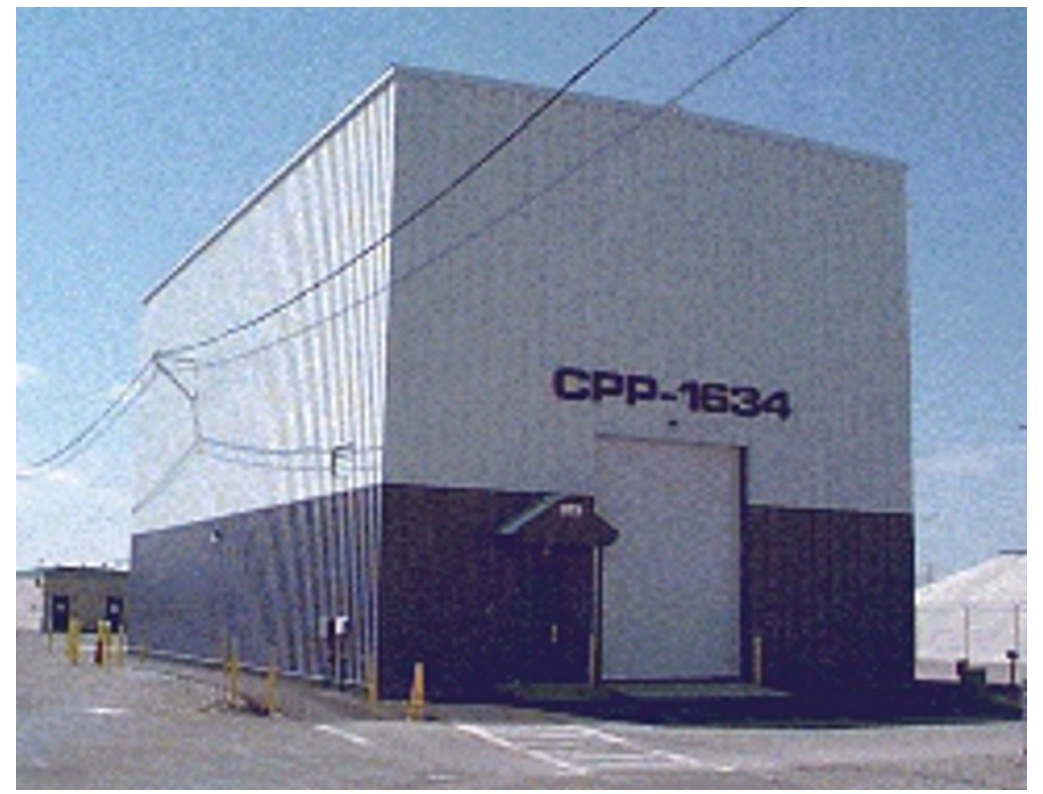

Figure 3. Building CPP-1634, located on the western edge of the Idaho Nuclear Technology and Engineering Center. The building is constructed as a large, high-bay space.

- The building is currently classified as a Less Than Hazard Category 3 (LTHC3) radiological facility, but at one time was classified as a HC-2 nuclear facility.

- The building footprint may not be sufficient to house HALEU fuel fabrication, but more than sufficient space could be provided by installing mezzanines to use upward space. Incorporation of an additional, mezzanine-level story is possible.

- There is neither appreciable ventilation equipment nor components that could be used for the fuel fabrication mission.

- The building is located inside the INTEC property protection area, formerly a Protected Area, so building access control should be relatively simple.

- INTEC is located roughly 20 miles away from MFC, adjacent to other INL-managed buildings and activities at INTEC, and near the Advanced Test Reactor and Remote-handled Low-Level Waste Facility. So, although CPP-1634 is not immediately adjacent to current fuel-fabrication activities at MFC, it lies near other INL support infrastructure. 
- Security impacts to HALEU operations in CPP-1634 would be limited to the access control requirements for the building. Other security functions do not impact HALEU operations and are covered under general INTEC security requirements.

\section{PROCESS AND EQUIPMENT DESCRIPTIONS}

The types of fuels considered in this study are metallic, ceramic, and intermetallic fuels (with ceramic and intermetallic fuels considered together as pellet types). Metallic fuels are made of uranium alloyed with other elements (typically zirconium), so the fuel retains a metallic form. Ceramic fuels are compounds in which a metal (uranium, in this case) is chemically combined with a non-metal, such as oxygen or nitrogen to form $\mathrm{UO}_{2}$ or uranium nitride (UN), respectively. Intermetallic fuels, such as uranium silicide $\left(\mathrm{U}_{3} \mathrm{Si}_{2}\right)$, are compounds of metal constituents, but are typically fabricated from powders in a manner similar to ceramic fuels. Most advanced-reactor designs use one of these types of fuel. Metallic fuels typically have been used in fast-spectrum reactors with liquid-metal coolants, while ceramic fuels have been used in both fast- and thermal-spectrum reactors. Metallic fuel fabrication usually begins with melting the fuel constituents together to form an alloy, after which the alloy is cast, either immediately or after solidification and reheating, or otherwise shaped to a specific form. Ceramic/intermetallic fuel fabrication is usually performed by synthesizing the compounds into powder form, followed by pressing and sintering the powders into solid pellets. Some design specifics that will bear on fabrication details include the means of thermally bonding the fuel material to the cladding (e.g., some fuel designs use a liquid metal [such as sodium, which is solid at room temperature but liquid at reactor operating temperatures] in the annular space between fuel and cladding, while other fuel designs might use helium in that gap or even eliminate the gap by pressing fuel and cladding together for a mechanical bond).

Although the specific steps and details for these fabrication processes vary for specific fuel designs, the processes can be described generically, but with sufficient detail, to allow preconceptual layout of fuel-fabrication equipment into facility spaces. This section describes the fabrication processes considered in this study.

The processes described below are based on the following assumptions:

- HALEU feedstock is obtained from EBR-II fuel processing in FCF with the intended ${ }^{235} \mathrm{U}$ enrichment, contaminated with approximately 100-ppm TRU contaminants

- Residual fission products in the HALEU feedstock have been removed such that it can be handled without extensive shielding (i.e., without requiring shielding walls as in hot cells, although containment of low-activity contamination would require gloveboxes)

- The typical batch sizes to be processed during fuel fabrication will be roughly 30 to $50 \mathrm{~kg}$ HALEU feedstock, depending on criticality-safety considerations

- The targeted throughput of each type of fabrication line, either metallic or ceramic, and irrespective of the building, will be $2.5 \mathrm{MTHM} / \mathrm{yr}$

- The quantities of fuel assumed to be fabricated will require the process to be operated within a double-HEPA-filtered, HC-2 nuclear facility.

\subsection{Metallic Fuel Process}

Typical metallic fuel-fabrication processes consist of the following six 6 stages:

1. Receipt of HALEU feedstock

2. Alloy production

3. Fuel casting or forming 
4. Final mechanical processing (shearing to length, machining, forming, etc.)

5. Encapsulation into cladding to form fuel rods

6. Final inspections.

Any fuel handling prior to hermitic enclosure of the cladding tubes will be performed in engineered enclosures (typically gloveboxes) to ensure personnel are not exposed to radioactive contamination. These stages are discussed in further detail below.

There are several means to produce metal products. Two methods, casting and extrusion, can be used to fabricate most metal-fuel configurations envisioned. Casting processes melt a fuel alloy for casting into molds that provide the desired shape. Typically, a cast metal-fuel "slug" will need to be clad with metal prior to use in a nuclear reactor. To promote heat transfer, low-melting-temperature metals (such as sodium) are used to thermally bond the fuel slug to the cladding.

Extrusion is a metal-forming process in which a piece of solid fuel alloy is pushed or drawn though a die to plastically deform the metal to a new shape. Depending on the metal and desired physical properties, the process can be done cold (unheated) or by heating the metal to a temperature with a preferred microstructural phase or level of plasticity to affect the final product. Extruded fuel slugs can be sodium bonded and clad in a manner similar to cast metals. However, the process also allows for the fuel alloy to be co-extruded with fuel cladding. This process eliminates the need for a bonding or heat-transfer metal; however, fission-gas release and the potential for fuel-clad interaction (corrosion) can become fueldesign issues.

HALEU Cleaning and Casting: Because the HALEU feedstock is coming from the FCF used-fuel treatment process, an initial cleaning step may be necessary. In most cases, this could be a simple external decontamination of the as-received ingots to minimize contamination spread to the gloveboxes. In some cases, depending on the condition of the HALEU feedstock, a mechanical or chemical cleaning may be necessary to remove oxide or slag layers. During the cleaning process, waste products will be generated. Following cleaning, the HALEU feedstock is ready for casting. Casting and alloying can be a one- or two-step process. In a single-step process, the HALEU feedstock and other alloying components, such as zirconium, are loaded into a crucible. The crucibles are usually coated with a non-reactive ceramic (typically yttrium oxide). The loaded crucible is placed into a furnace and heated, usually to approximately $1500^{\circ} \mathrm{C}$ and held for approximately 1 to 2 hours to melt and mix (either with a rotating stirrer or with inductive stirring) the constituents into a homogeneous alloy. The exact casting temperature used will depend on alloy composition and specific process needs. The molten alloy is then poured or injected into a mold of specific shape. In a two-step process, the material is melted and poured into an interim shape, usually sized for convenient handling. The first casting step is used to ensure chemical homogeneity and to allow inspection for the proper chemical composition. During the second casting step, the product is re-melted and cast into the desired final fuel form. Casting operations with molten uranium alloys form an oxide slag or dross. This dross is a waste stream that will require disposal or, preferably, eventual recycle into a new casting batch. Crucibles can generally be re-used for 10 to 20 cycles; however, the non-reactive coating must be removed and re-applied after each casting process. In the past, single-use quartz molds have been used for solidifying the cast metal into the desired shape, but those molds must be disposed as waste after each use. Developments in recent years may allow use of re-useable fuel molds, which would reduce the amount of casting-process waste.

Mechanical Processing: Industry and research organizations have communicated interest in a number of metallic fuel forms. Some fuel forms can be geometrically complex, while others may be simple right cylinders. Depending on the final fuel form, mechanical processing of fuel to final shape could be as simple as cutting or shearing a fuel slug to final length. However, more complicated processes of machining, extrusion, drawing, or other forming methods might be needed. If the fuel is a traditional rod-type, a simple shearing process is usually all that is required. Fuel-slug end trimmings can typically 
be recycled into a subsequent casting batch. If machining is required, machine chips will be produced that may be recycled or disposed, depending on available recycle processes. Given the low availability and intrinsic high value of HALEU, recycling the machining-scrap is likely warranted. Additional fuel shaping could include hot forming activities, such as extrusion, in which the fuel is heated to 600 to $900^{\circ} \mathrm{C}$ and forced through a die. This may require a subsequent cleaning step to remove potential lubricants or surface oxides. Further mechanical processing and heat treatments $\left(500\right.$ to $850^{\circ} \mathrm{C}$ for less than 60 minutes), might also be needed to obtain the needed physical and microstructural characteristics.

Encapsulation: After the fuel has been formed and inspected, it is ready for encapsulation into a cladding tube, which forms the fuel rod or fuel element. The cladding tubes will be brought into the facility from an offsite vendor. Cladding tubes are usually either a stainless steel, such as 316SS or $421 \mathrm{SS}$, a high-alloy steel, such as a 9Cr-1Mo steel, or zirconium alloy. In the case of a liquid-metal bonded fuel, the cladding tubes may be pre-loaded with the bond metal (e.g., sodium) by the supplier, or this operation can be performed in the fuel-fabrication facility.

Fuel slugs may be loaded either vertically or horizontally into cladding tubes (or cladding "jackets") that are closed on one end. After the cladding tube is loaded, the open end is closed with an end plug that is welded into place. At this point, the fuel is encapsulated and can be handled outside the glovebox if further processing is required. .Further treatment may include heat treatment of the welds, heating the liquid-metal bond material, or wire wrapping of the fuel rods for proper spacing in the reactor. Heat treatment of the welds, if necessary, is typically performed at temperatures lower than $800^{\circ} \mathrm{C}$ for less than 30 minutes. If the metal bond material must be heated, the final temperature will depend on the properties of the metallic bond material; in the case of sodium, the sealed tube is heated to approximately $500^{\circ} \mathrm{C}$ for up to 1 hour. The seal-welded fuel rods are inspected to ensure closure and compliance of final dimensions and other attributes, and then released for subsequent assembly into fuel subassemblies.

\subsection{Ceramic/Intermetallic Fuels Process}

The fabrication of fuels from three representative fuel compounds is briefly outlined here: $\mathrm{UO}_{2}, \mathrm{UN}$, and $\mathrm{U}_{3} \mathrm{Si}_{2}$ (other compound/ceramic fuels could also be fabricated with limited changes to the production line).

HALEU Cleaning: Because the HALEU feedstock is produced by the FCF used-fuel treatment process, which leaves some residual contaminants, an initial cleaning step may be necessary. In most cases this could be a simple external decontamination of the as-received ingots to minimize contamination spread to the gloveboxes. In some cases, depending on the condition of the HALEU feedstock, a mechanical or chemical cleaning may be necessary to remove oxide or slag layers. During the cleaning process, waste products will be generated.

Powder Production: Production of uranium oxide powder can be accomplished in two ways: aqueous conversion (wet process) and direct oxidation (dry process). Both wet and dry processes require a milling step before granulation to reduce the particle size, because both processes involve heating, which can result in aggregated powder. The target particle size and distribution will depend on the target sintered density. Commercial fabricators of uranium oxide fuel have found that a broad range of particle sizes is acceptable (between 10 and $45 \mu \mathrm{m}$ ).

Direct oxidation simply oxidizes the uranium metal directly with oxygen in a process known as calcining. This involves a controlled-atmosphere furnace with an agitation system to separate the oxidized material as it reacts. The oxidation process leaves powder in a mix of oxidation states, so the powder needs to undergo another heating cycle in a reducing atmosphere to transform all the material into $\mathrm{UO}_{2}$. The resultant material requires granulation and milling to form powder with characteristics suitable for pressing with the rotary press used to produce the pellets. 
An aqueous conversion process consists of dissolving the FCF metallic HALEU feedstock into an acid, such as nitric acid, hydrochloric acid, or a nitric-sulfuric acid mixture, followed by heating of the acid solution in air to form a uranium oxide powder. Although aqueous conversion is preferred to produce $\mathrm{UO}_{2}$ powder requiring the least amount of powder processing for successful pelletization, the capital costs and space required for an aqueous process would be extensive. For that reason, this study addresses only direct oxidation as the primary alternative.

In the process assumed for this study, $\mathrm{U}_{3} \mathrm{Si}_{2}$ powder is formed by first alloying silicon with the FCF metallic HALEU feedstock. Preferential loss of silicon during initial melting is minimized by using an arc-melting furnace to produce the uranium silicon alloy. After additional homogenization melts, the ingot is mechanically broken up and ball-milled to reduce the material particle size to the specified powder size. The milling media will occasionally need to be replaced, with the used media disposed as waste.

UN is made in research quantities via two methods: 1) hydride-dehydride/nitride-denitride (i.e., forming uranium hydride, then decomposing the hydride to form powder that is then nitrided to form uranium nitride) and 2) carbothermic reduction of uranium oxide. Because the carbothermic reduction path is used with a uranium oxide feedstock and results in high carbon contamination, it is not considered for this process. The hydride-dehydride/nitride-denitride process consists of heating the bulk uranium in a hydrogen atmosphere (the optimal temperature is $225^{\circ} \mathrm{C}$ ) until the uranium has reacted with hydrogen, followed by introduction of vacuum (still at temperature) until the material has turned into a fine powder. At this point the process is repeated with nitrogen (the denitriding step reduces the material from $\mathrm{U}_{2} \mathrm{~N}_{3}$ to the required $\mathrm{UN}$ ).

Pellet Production: Following powder manufacture, fuel pellets are formed using an industrystandard pelletizing process. Each type of powder would require optimized pelletizing parameters, with variables such as binder, die lubrication, and pressing parameters evaluated. The residual contaminants expected to be present in the HALEU feedstock will necessitate that all powder and pelletizing operations be performed within containment gloveboxes. Depending on the characteristics and chemical reactivity of the powder, the pelletizing process might need to be contained in inert-atmosphere gloveboxes. For example, uranium silicide powder is potentially pyrophoric and must be handled away from atmospheric air.

The prepared fuel powder is fed into a rotary die where the material is pressed at room temperature to form "green" pellets (i.e., pellets that have been pressed from powder, but not yet sintered into non-friable pellets). Green pellets are subsequently heated in a sintering furnace (at temperatures ranging from 1450 to $2000^{\circ} \mathrm{C}$ ). The atmosphere of the furnace needs to vary depending on the material: silicide fuel requires an inert atmosphere while oxide and nitride need a reducing atmosphere, such as dry argon with a small amount of hydrogen.

Following sintering, pellets are ground to final diameter using centerless grinders (the desired length and end chamfer are imparted during pelletizing). Following quality inspection, the pellets are ready to be encapsulated into fuel rods.

Dimensions of commercial LWR fuel pellets tend to range in diameters of 0.3225 inches in. to 0.394 inches in. (8.2 to $10 \mathrm{~mm}$ ) with lengths of 0.394 inches in. to 1 inches in. (10 to $25.4 \mathrm{~mm})$. The longer pellet designs have fallen out of favor due to the potential for pellet "hour glassing" that results from small differences in green-pellet density across the length of the pellet. Ceramic pellets are typically "dished" on the ends to accommodate pellet swelling during operation. Pellets are chamfered at the edges to preclude chipping (which can induce binding loads during rod assembly) and hot spots in service. 
Encapsulation: Fuel pellets approved by inspection are laid out in channeled trays in single columns. After the proper number of pellets are arranged into columns, the pellet columns are pushed horizontally into a horizontal cladding tube that is sealed on one end. The cladding tubes will be brought into the facility from an offsite vendor. Cladding tubes are usually either a stainless steel, such as $316 \mathrm{SS}$ or $421 \mathrm{SS}$, a high-alloy steel, such as a 9Cr-1Mo steel, or an alloy of zirconium. After the cladding tube is loaded, the open end is closed with an end plug that is welded into place. The seal-welded fuel rods are inspected to ensure closure, final dimensions, and other attributes, and then released for subsequent assembly into fuel subassemblies.

\section{Final Assembly}

Enclosed and inspected fuel rods or fuel elements are typically incorporated into larger fuel assemblies, or perhaps assembled into a test assembly or test fixture. Because a variety of different fuel designs using HALEU have been proposed by reactor developers, there is no single fuel assembly concept in view. However, examples of fuel assemblies include square or hexagonal bundles of fuel rods held together by fuel assembly components, such as grid plates and grid spacers. The assembly procedures are expected to be simple, mechanical processes with no direct handling or processing of the nuclear material. The processes might include welding of stainless steel or zirconium assembly components.

\section{FABRICATION FUNCTIONS AND EQUIPMENT}

Using the proposed production rate of $2.5 \mathrm{MTHM} / \mathrm{yr}$, and the general production schemes detailed in the preceding sections, representative fuel-fabrication equipment was envisioned. The functions for the envisioned metal and ceramic fabrication processes were determined to identify needed equipment and suitable glovebox configurations. The overall flow of the work was developed such that logical break points would coincide with specific gloveboxes. In that way, the work could be divided to separate radiologically "dirty" work from cleaner activities. For example, to reduce contamination potential for downstream parts of the process, powder-preparation activities would not be combined with sintering or final assembly of pellets into a fuel rod. The functional activities, along with their encompassing gloveboxes, were arranged within each facility footprint to establish potential work and material flow through a facility.

\subsection{Metal Casting}

Although metal alloys can be cast in any of several methods, the injection casting process used to produce fuel for Experimental Breeder Reactor II (EBR-II) at MFC (formerly Argonne National Laboratory-West) is used here as the reference process for identifying equipment and process flow within the proposed facilities. Table 1 lists gloveboxes that would be required, the functions that will be performed in them, and a list of major equipment items needed to perform those functions. Injection casting has successfully produced metal fuel slugs with diameters between 0.18 inches and 0.30 inches $(4.5$ and $7.6 \mathrm{~mm})$ and lengths to 19 inches $(483 \mathrm{~mm})$. This process produces versatile fuel slugs; used in stacks, fuel rods can be made for a fast reactor core of 31.5 inches $(800 \mathrm{~mm})$ or more.

Table 1. Glovebox requirements for casting and producing metal fuels.

\begin{tabular}{|l|l|l|}
\hline \multicolumn{1}{|c|}{ Glovebox/Station } & \multicolumn{1}{|c|}{ Function } & \multicolumn{1}{c|}{ Equipment } \\
\hline Casting Glovebox & Receipt of fuel alloy & $\begin{array}{l}\text { Weight balance for preparing alloy, and recording } \\
\text { weights for material balance and tracking }\end{array}$ \\
\cline { 2 - 3 } & $\begin{array}{l}\text { Receipt of pre-assembled mold pallets } \\
\text { (with w/ molds) }\end{array}$ & - \\
\cline { 2 - 3 } & Furnace crucible preparation and loading & - \\
\cline { 2 - 3 } & Casting & Casting furnace assembly \\
\cline { 2 - 3 } & $\begin{array}{l}\text { Transfer cast molds/pallet to demolding } \\
\text { glovebox }\end{array}$ & $\begin{array}{l}\text { Transfer container capable of holding } \sim 20 \mathrm{~kg} \text { of fuel } \\
\text { alloy }\end{array}$ \\
\hline
\end{tabular}


Table 1. (continued).

\begin{tabular}{|c|c|c|}
\hline Glovebox/Station & Function & Equipment \\
\hline \multirow[t]{5}{*}{ Demolding Glovebox } & Break molds from pallet & - \\
\hline & Separate fuel slug from mold & $\begin{array}{l}\text { Mold removal device, quartz waste collection } \\
\text { container }\end{array}$ \\
\hline & Fuel slug inspection and marking & $\begin{array}{l}\text { Examination station (microscope with surface } \\
\text { analysis capability, ability to mark slugs for records } \\
\text { purposes) }\end{array}$ \\
\hline & Fuel slug trimming, reject slug breakup & $\begin{array}{l}\text { Trim and reject slug collection can (for transfer back } \\
\text { to casting glovebox), transfer containers for } \\
\text { analytical laboratory samples, balance for recording } \\
\text { slug weight }\end{array}$ \\
\hline & $\begin{array}{l}\text { Packaging for transfer to processing } \\
\text { glovebox }\end{array}$ & Transfer container \\
\hline \multirow[t]{7}{*}{ Processing Glovebox } & Receive cladding jackets, upper end plugs & - \\
\hline & Final slug inspection & Straightness table \\
\hline & Sodium slug preparation & $\begin{array}{l}\text { Balance for weight of sodium used, sodium press to } \\
\text { make rodlets }\end{array}$ \\
\hline & $\begin{array}{l}\text { Fuel rod assembly (insert sodium, fuel } \\
\text { slugs, upper end plugs) }\end{array}$ & Assembly station \\
\hline & Weld upper end fitting in place & Welder and welding station \\
\hline & Decontamination & Decontamination station \\
\hline & Leak check & Helium-leak checker \\
\hline \multirow[t]{2}{*}{$\begin{array}{l}\text { Rod Settling and } \\
\text { Bonding Station }\end{array}$} & $\begin{array}{l}\text { Heat rods, tap rods, to allow sodium to } \\
\text { encompass the fuel slugs and bond the } \\
\text { fuel slug to the cladding jacket. }\end{array}$ & Rod settling and bonding station \\
\hline & $\begin{array}{l}\text { Inspection (to ensure adequacy of sodium } \\
\text { bonding) }\end{array}$ & Radiography station (X-ray) \\
\hline Spacer Wire Station & Attach spacer wire to the fuel rod & Wire winding machine, welder \\
\hline \multirow[t]{2}{*}{$\begin{array}{l}\text { Subassembly } \\
\text { Fabrication Station }\end{array}$} & Fuel subassembly manufacture & $\begin{array}{l}\text { Vertical assembly device (an apparatus that holds all } \\
\text { the fuel rods in place while the subassembly is } \\
\text { assembled) }\end{array}$ \\
\hline & Final inspection & Metrology tools \\
\hline Storage & $\begin{array}{l}\text { Space to store completed subassemblies } \\
\text { prior to shipment }\end{array}$ & - \\
\hline
\end{tabular}

\subsection{Metal Extrusion}

The largest difference between metal extrusion and metal casting is the method used to form and inspect the finished (or semi-finished) fuel alloy shape. In the current study, an extrusion fabrication line is envisioned in which the fuel alloy-casting station is replaced by a fuel alloying furnace (to achieve the shaped needed to feed the extrusion press - typically a bar of material) and an extrusion press, and the demolding process is replaced with a quality control inspection glovebox (a QA/QC glovebox) for additional inspection of the extruded fuel slugs.. The remaining processes to produce the fuel rods and subassemblies are the same. Table 2 addresses the substitution of an extrusion glovebox for the casting and demolding gloveboxes presented in Table 1. 
Table 2. Glovebox requirements for extruding and producing metal fuels.

\begin{tabular}{|c|c|c|}
\hline Glovebox/Station & Function & Equipment \\
\hline \multirow[t]{5}{*}{ Extrusion Glovebox } & Receipt of fuel alloy & $\begin{array}{l}\text { Weight balance for preparing alloy, and recording } \\
\text { weights for material balance and tracking }\end{array}$ \\
\hline & Perform alloying (as necessary) & $\begin{array}{l}\text { High-temperature furnace with bottom pour } \\
\text { capability to pour alloy into molds that feed the } \\
\text { extrusion press. }\end{array}$ \\
\hline & Metal extrusion & Extrusion press \\
\hline & Casting & Casting-furnace assembly \\
\hline & Transfer extrusions to QA/QC glovebox & $\begin{array}{l}\text { Transfer container capable of holding } \sim 20 \\
\text { extrusions }\end{array}$ \\
\hline \multirow[t]{3}{*}{ QA/QC Glovebox } & Inspect extrusions & $\begin{array}{l}\text { Metrology tools for dimensional analyses, visual } \\
\text { inspection microscope, photography, sample } \\
\text { trimming for analytical chemistry }\end{array}$ \\
\hline & Straighten extrusions & Straightening table \\
\hline & Packaging for transfer to processing glovebox & Transfer container \\
\hline \multirow[t]{7}{*}{ Processing Glovebox } & Receive cladding jackets, upper end plugs & - \\
\hline & Final slug inspection & Straightness table \\
\hline & Sodium slug preparation & $\begin{array}{l}\text { Balance for weight of sodium used, sodium press } \\
\text { to make rodlets }\end{array}$ \\
\hline & $\begin{array}{l}\text { Fuel rod assembly (insert sodium, fuel slugs, } \\
\text { upper end fitting }\end{array}$ & Assembly station \\
\hline & Weld upper end fitting in place & Welder and welding station \\
\hline & Decontamination & Decontamination station \\
\hline & Leak check & Helium leak checker \\
\hline \multirow[t]{2}{*}{$\begin{array}{l}\text { Rod Settling and } \\
\text { Bonding Station }\end{array}$} & $\begin{array}{l}\text { Heat rods, tap rods, to allow sodium to } \\
\text { encompass the fuel slugs and bond the fuel } \\
\text { slug to the cladding jacket. }\end{array}$ & Rod settling and bonding station \\
\hline & $\begin{array}{l}\text { Inspection (to ensure adequacy of sodium } \\
\text { bonding) }\end{array}$ & Radiography station (X-ray) \\
\hline Spacer Wire Station & Attach spacer wire to the fuel rod & Wire winding machine, welder \\
\hline \multirow[t]{2}{*}{$\begin{array}{l}\text { Subassembly } \\
\text { Fabrication Station }\end{array}$} & Fuel subassembly manufacture & $\begin{array}{l}\text { Vertical assembly device (an apparatus that holds } \\
\text { all the fuel rods in place while the subassembly is } \\
\text { assembled) }\end{array}$ \\
\hline & Final inspection & Metrology tools \\
\hline Storage & $\begin{array}{l}\text { Space to store completed subassemblies prior } \\
\text { to shipment }\end{array}$ & \\
\hline
\end{tabular}




\subsection{Ceramic/Intermetallic Fuel Fabrication}

The illustrative process considered here for ceramic/intermetallic fuel synthesis is oxidation of the HALEU metal fuel alloy to an oxide powder, followed by further conversion, if necessary (e.g., to a nitride), then processing to produce densified fuel pellets, which are ground on centerless grinders. Completed pellets are then loaded into cladding. Depending on the reactor type, the cladding can be sealed under inert cover gas, or the pellets (if nitride) can be bonded to the clad with sodium, as is done for fast-reactor metal fuels.

The reference pellet production process assumes the manufacture of pellets of about 0.35 inches $(9$ $\mathrm{mm})$ diameter by 0.39 inches $(10 \mathrm{~mm})$ long. Table 3 contains a listing of those gloveboxes that would be required for ceramic pellet manufacture and fuel-rod assembly, the functions that will be performed in them, and a list of major equipment items needed to perform those functions.

Table 3. Glovebox requirements for ceramic/intermetallic fuel production.

\begin{tabular}{|c|c|c|}
\hline Glovebox/Station & Function & Equipment \\
\hline \multirow[t]{2}{*}{$\begin{array}{l}\text { Clean Feedstock } \\
\text { Glovebox }\end{array}$} & Receipt of fuel alloy, cleaning & $\begin{array}{l}\text { Weight balance recording weights for material } \\
\text { balance and tracking, material cleaning station } \\
\text { (fuel alloy surface cleaning) }\end{array}$ \\
\hline & $\begin{array}{l}\text { Receipt of pre-assembled mold pallets (w/ } \\
\text { molds) }\end{array}$ & - \\
\hline \multirow{4}{*}{$\begin{array}{l}\text { Material Preparation } \\
\text { Glovebox }\end{array}$} & Conversion of metal to ceramic & Controlled-atmosphere furnaces \\
\hline & Batch weighing, rough powder sizing & $\begin{array}{l}\text { Balance for weighing, microscope for powder } \\
\text { examination }\end{array}$ \\
\hline & Powder packaging for transfer & Canning station \\
\hline & Glovebox cleaning & In-box vacuum cleaner, waste containers \\
\hline $\begin{array}{l}\text { Powder Processing } \\
\text { Glovebox }\end{array}$ & $\begin{array}{l}\text { Powder comminution, blending, admixture } \\
\text { preparation This is where the rough, converted } \\
\text { powder is prepared for use in preparing pellets. } \\
\text { The powder is conditioned (e.g., ball milling), } \\
\text { binders and lubricants are added, and } \\
\text { characterized to ensure consistent performance } \\
\text { in pressing and sintering. }\end{array}$ & $\begin{array}{l}\text { Balance for weighing, microscope, surface area } \\
\text { analyzer, particle size analyzer. }\end{array}$ \\
\hline \multirow[t]{2}{*}{ Pressing Glovebox } & $\begin{array}{l}\text { Green pellets are pressed using a rotary-type } \\
\text { press. These presses make consistent pellets, } \\
\text { repeatedly, with little maintenance. }\end{array}$ & $\begin{array}{l}\text { Rotary pellet press, small uniaxial press and dies } \\
\text { (for batch testing prior to production) }\end{array}$ \\
\hline & Pellet metrology/inspection & $\begin{array}{l}\text { Metrology tools (micrometer and balance to } \\
\text { measure pellet green size and to calculate green } \\
\text { density), camera to document pellets }\end{array}$ \\
\hline \multirow[t]{3}{*}{ Sintering Glovebox } & $\begin{array}{l}\text { Pellets are heated in controlled-atmosphere } \\
\text { furnaces up to } 2,000^{\circ} \mathrm{C} \text { to sinter the green } \\
\text { pellets to a consolidated product. }\end{array}$ & Two controlled-atmosphere furnaces \\
\hline & QA spot check & $\begin{array}{l}\text { Balance for weighing, metrology tools for } \\
\text { dimensional analysis }\end{array}$ \\
\hline & Canning pellets for transfer to next process & Transfer containers \\
\hline \multirow[t]{2}{*}{ Grinding Glovebox } & $\begin{array}{l}\text { A centerless grinder is used to obtain precise } \\
\text { pellet dimensions. }\end{array}$ & - \\
\hline & QA spot check & $\begin{array}{l}\text { Balance for weighing, metrology tools for } \\
\text { dimensional analysis }\end{array}$ \\
\hline
\end{tabular}


Table 3. (continued).

\begin{tabular}{|c|c|c|}
\hline Glovebox/Station & Function & Equipment \\
\hline \multirow[t]{2}{*}{ Cleaning Glovebox } & $\begin{array}{l}\text { Pellets are cleaned in a solution suitable for the } \\
\text { material being pressed (e.g., aqueous, weak } \\
\text { alcohol solution), then dried. }\end{array}$ & Ultrasonic cleaners, pellet dryer \\
\hline & Canning pellets for transfer to next process & Transfer containers \\
\hline QA Glovebox & Detailed pellet QA/QC and documentation & $\begin{array}{l}\text { Immersion density device, microscope, } \\
\text { photography station, dimensional analysis station, } \\
\text { balance for weighing, sample preparation station } \\
\text { for analytical laboratory }\end{array}$ \\
\hline \multirow{7}{*}{$\begin{array}{l}\text { Element Assembly } \\
\text { Glovebox }\end{array}$} & Receive cladding and end plugs & - \\
\hline & Place pellets in cladding & - \\
\hline & Final inspection & Straightness table \\
\hline & Weld end fitting in place & Welder and welding station \\
\hline & Decontamination & Decontamination station \\
\hline & Leak check & Helium leak checker \\
\hline & Remove fuel rod from glovebox & - \\
\hline
\end{tabular}

\section{FACILITY LAYOUTS}

Layouts of oxide and metal fuel-fabrication lines in each of the three selected facilities are presented in this section. A key result is the determination that accommodation of the fabrication lines is feasible in each of the facilities, although specific production capacity (i.e., fabrication rate) will likely depend on each facility's available space. Facility and cost of facility preparation costs and, and equipment installation might favor certain facilities over others. For the purposes of the present study, the representative processes of metal casting and oxidation conversion of metal for oxide production are considered. The complexity and overall space requirements for these two methods are sufficiently representative of the envisioned variants in processes.

The space required for each of the basic fabrication processes was estimated, and appropriately sized gloveboxes were sketched. These gloveboxes were then laid-out in the facilities using simple threedimensional models to determine if the process equipment can fit within the available space. In some cases, gloveboxes can be connected end-to-end; in others, the floor space configuration does not allow certain gloveboxes to be connected. At this time, contiguous connection of gloveboxes was not considered to make one facility configuration more or less favorable than another, because materials and samples can be transferred relatively easily between gloveboxes, using transfer containers, as needed. Also, no effort was made to resize gloveboxes and process equipment for optimal facility-specific layout.

\subsection{MFC-798 Radioactive Liquid Waste Treatment Facility (RLWTF)}

MFC-798 is a two-story building, constructed from reinforced concrete masonry units. Process operations for either metal casting or ceramic-fuel production would need to be split between the two floors. For this analysis, no major facility modifications were considered (beyond enlarging existing door frames).

\subsubsection{Ceramic/Intermetallic Fuel Fabrication}

Ceramic/intermetallic fuel-fabrication flow in MFC-798 would begin on the second floor and finish on the first floor. Ideally, the work flow would follow the order presented in Table 3. However, in this design study, the sizes of the glove boxes were held constant, rather than sized for a specific process (i.e., 
oxide, nitride, pellet size, and final form are not specified for this current study), so the work flow is arranged based on space available to accommodate gloveboxes, rather than in an optimal manner. If warranted, the process steps and glovebox sizes could be adapted to better fit the work into the space available. Material would then flow between the floors only once.

Figure 4 shows the second floor, where the process line would begin. In this configuration, the feedstock is received through the clean feedbox glovebox. Any steps necessary to clean the fuel alloy (e.g., remove an oxide skin or simply wash the alloy) would be performed. If necessary, the alloy ingots could be broken into smaller pieces. Next, the alloyed material would move to the materials-preparation glovebox, where the metal would be converted to a compound, powder form. The powder would be collected and placed into transfer cans for transfer to the powder-processing glovebox, located on the first floor see Figure 5. This glovebox contains the equipment needed to process the rough powder that was converted from the metal alloy. From there, the powder would move to the pressing glovebox to be pressed into green pellets. Next, the pellets would be loaded into the sintering glovebox and sintered. Following sintering, the pellets would be transferred back upstairs to the grinding glovebox to be fed into a centerless grinder for proper sizing. A Quality Assurance Glovebox installed on the second floor would be used for off-line inspection and analysis of pellets to ensure conformance to pellet specifications. The pellets would then be cleaned (if necessary) in the cleaning glovebox to prepare the pellets for loading into cladding tubes. In this scheme, the pellets would be moved down to the first floor for assembly into fuel rods in the element-assembly glovebox. Once completed, the fuel rods would be inspected for hermetic closure and for conformance to other fuel rod specifications.

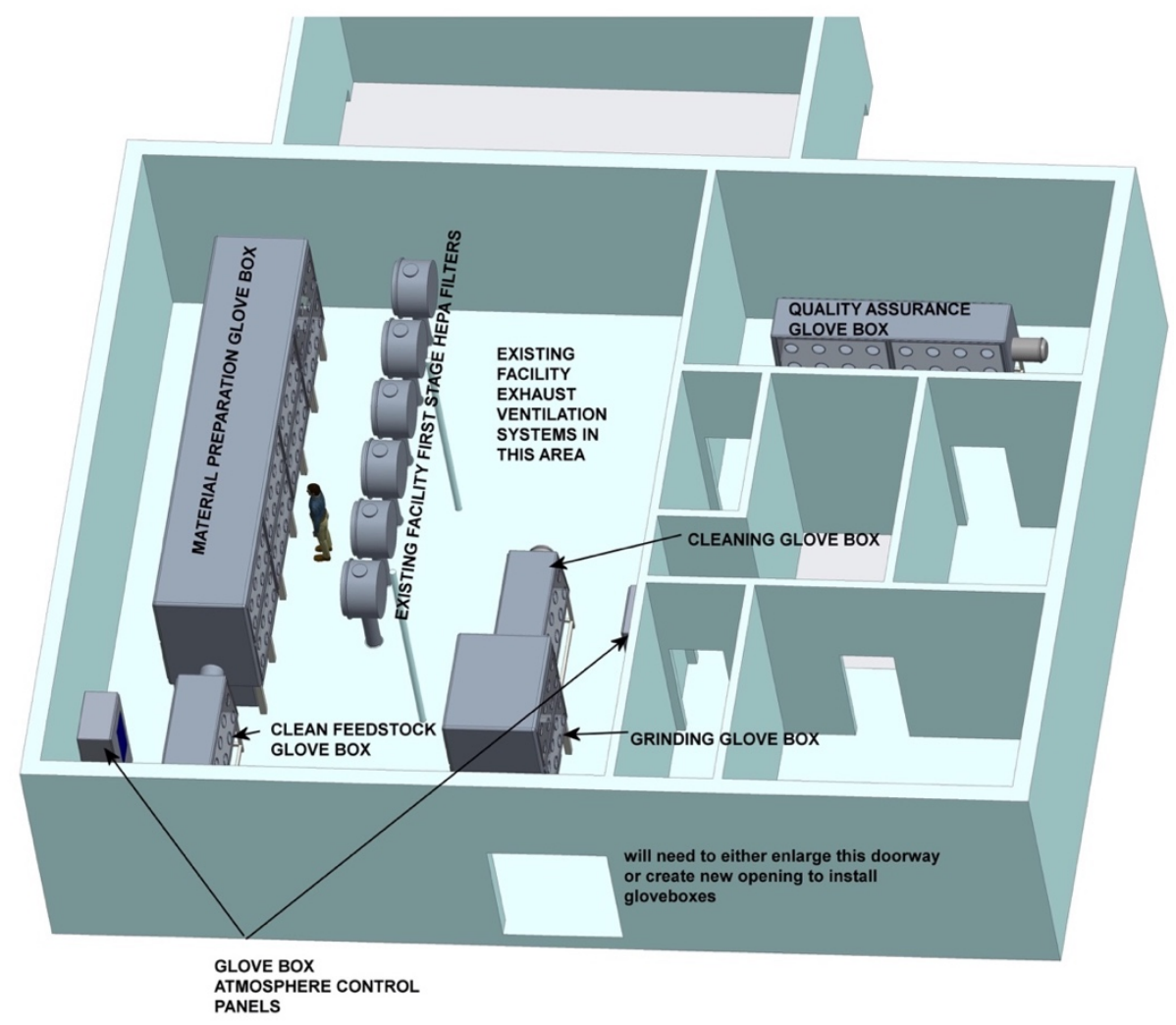

Figure 4. Second floor of the RLWTF where ceramic/intermetallic fuel production would begin. 


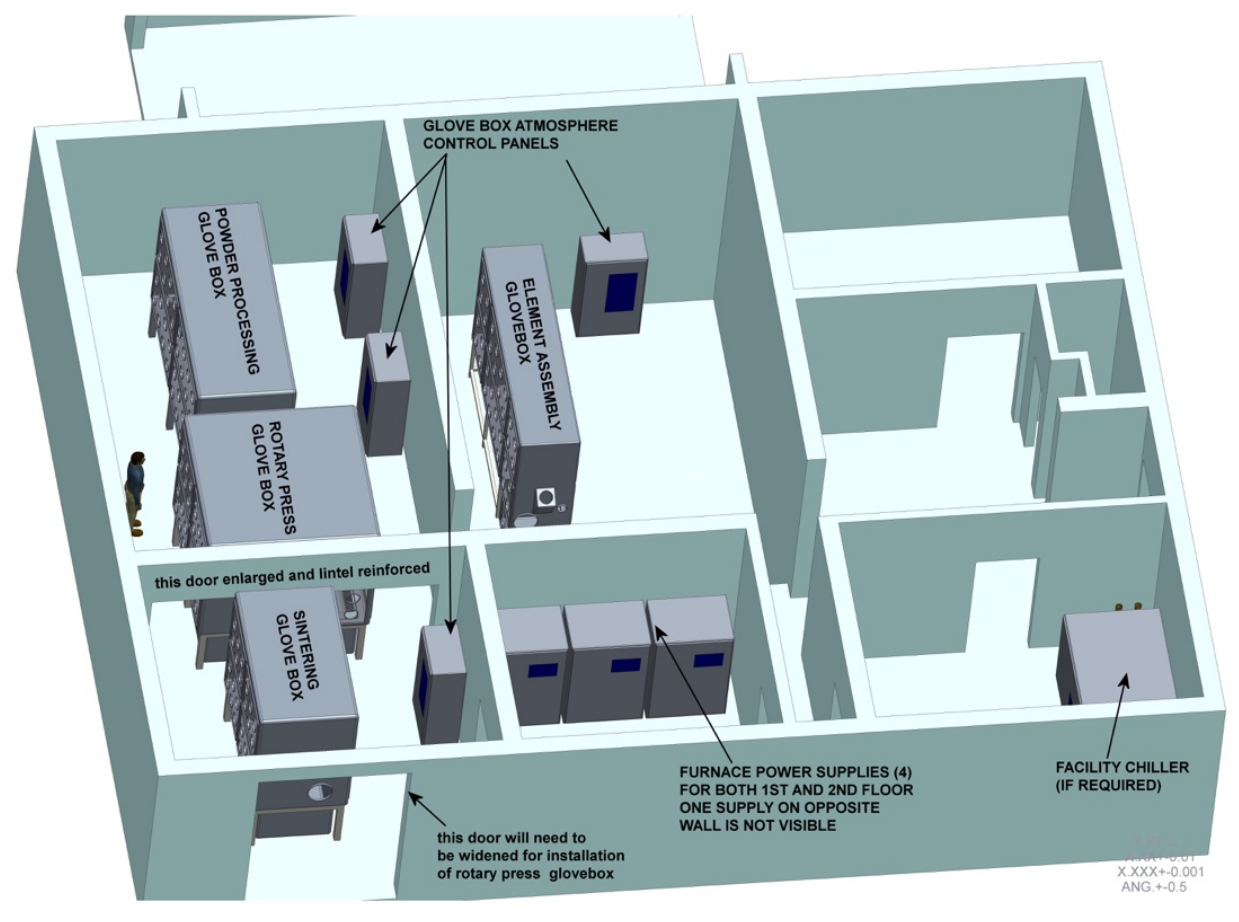

Figure 5. First floor of the RLWTF where ceramic/intermetallic fuel work would be completed.

\subsubsection{Metal Fuel Fabrication}

As illustrated in Figures 6 and 7, production of metal fuel in RLWTF would begin on the first floor. Two casting-furnace gloveboxes on the first floor can support a single fuel-element assembly line on the second floor. The casting gloveboxes are sized to allow injection casting of two batches of about $15 \mathrm{~kg}$ metal alloy in a single day. Each line could reasonably be expected to operate two times per week (allowing for maintenance between runs).

Several operations would take place in a casting glovebox: the fuel alloy would be prepared, the alloy cast into molds, the alloy cooled, and the molds removed from the casting furnace. Next, the molds would be removed from the cast metal alloy slugs. The slugs would be cleaned and given an initial inspection. Any rejected fuel slugs would be culled for recycle in future casting batches. The slugs would then be loaded into containers for transfer to the second floor for slug processing.

The slugs would be weighed, trimmed to length, and measured dimensionally. Some end trimmings could be used as analytical chemistry samples, but most would be recycled into the next casting batches. The cladding jackets would be brought into the element-assembly glovebox for fuel loading. If the rods were to be sodium bonded, using the Processing Glovebox, sodium metal would be weighed and pressed into rodlet shapes suitable for loading into cladding jackets. The sodium would be loaded into the "bottom" of the cladding jacket, and fuel slugs would be inserted on top of the sodium. The rods would be closed by insertion and welding of the top end plug. Following closure welding, the rods would be inspected and leak checked. The rods could then be placed in a settling furnace to melt the sodium, which settles the sodium to wet and fill the annular space between the fuel slugs and cladding, thermally bonding the fuel and cladding. The rods would be visually inspected again, and the sodium bond quality would be inspected by x-radiography.

In this evaluation, the production process is finished with the completion of individual fuel rods, although there is room in the building to support assembling those individual rods into larger assemblies as needed for a specific fabrication campaign. 
Although the corresponding equipment layout is not shown, the facility is also large enough to accommodate metal-extrusion operations. The casting furnaces would be replaced by one or two extrusion presses and an ingot-forming furnace. The presses would require confinement within an enclosure to protect workers and the facility. Raw extrusions would be transferred to the second floor, where the production of fuel rods could be nearly identical to that used for cast fuel slugs. Figures 6 and 7 show the layout of gloveboxes for metal fuel production in RLWTF.

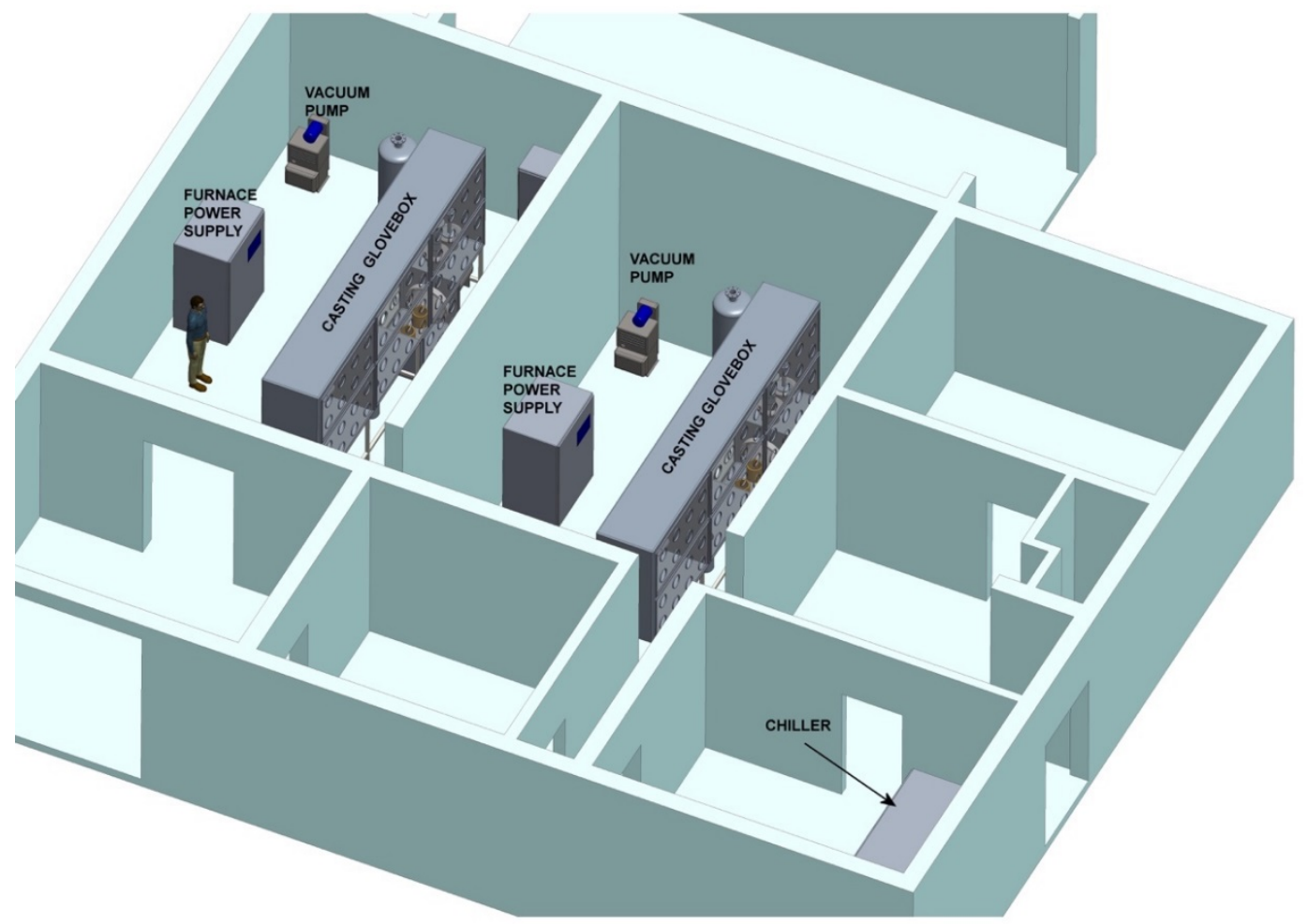

Figure 6. Metal fuel production begins on the first floor of RLWTF. Two casting furnaces are provided in two separate gloveboxes. 


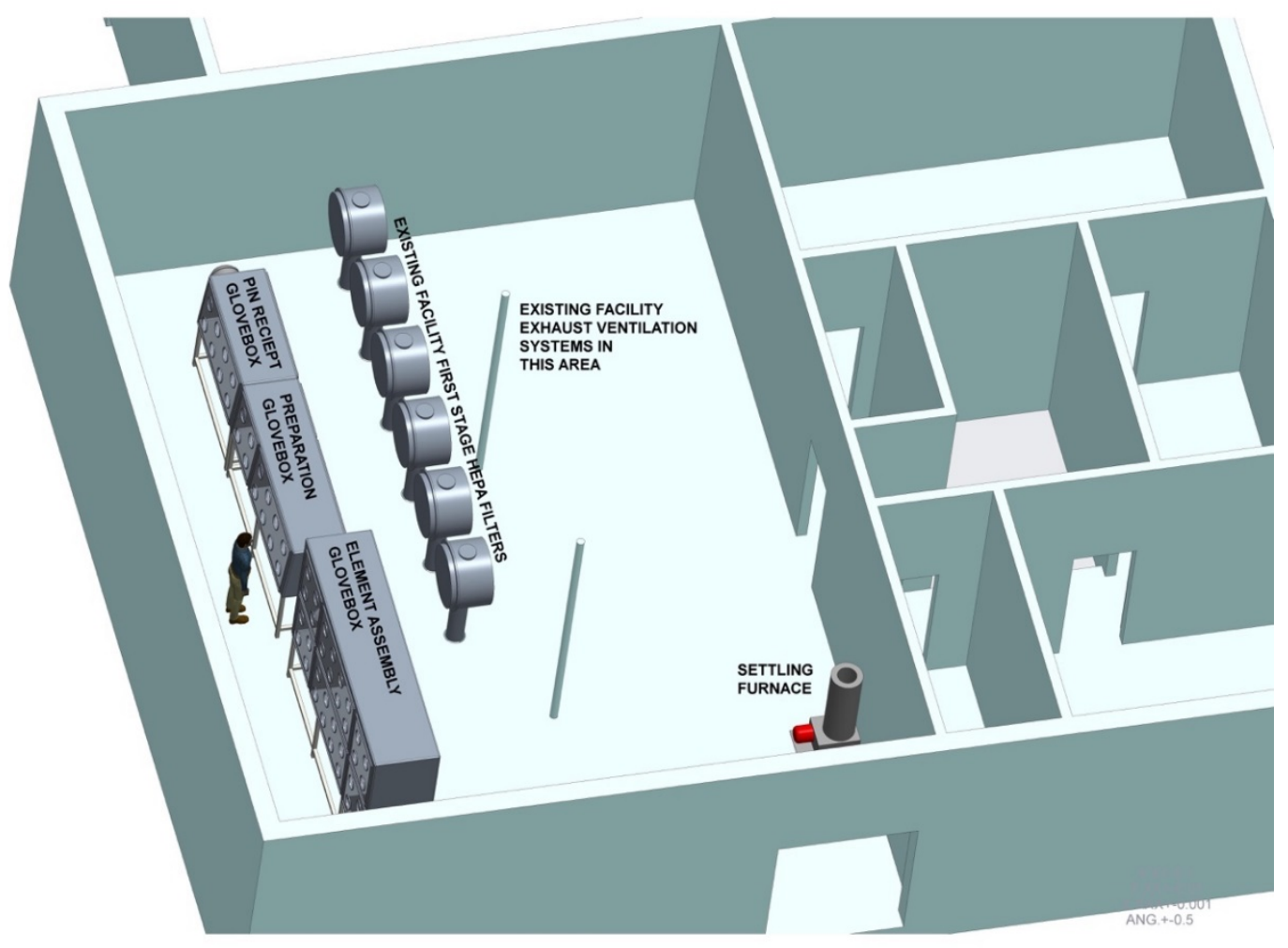

Figure 7. RLWTF second floor layout for metal fuel production.

\subsection{MFC-765 (FCF) Mockup Shop}

The FCF Mockup Shop occupies about 3,500 $\mathrm{ft}^{2}\left(325 \mathrm{~m}^{2}\right)$ on the north side of building MFC-765. No major modifications were considered for this space It is the only space considered that is located within a currently-authorized HC-2 nuclear facility.

\subsubsection{Ceramic/Intermetallic Fuel Fabrication}

The process follows the logic shown in Table 3. Unlike the example for RLWTF, all operations can be located on one floor. The one unusual disconnect in the process line requires container transfer of finished pellets from the cleaning glovebox to the element-assembly glovebox. The equipment and glovebox layout can be optimized to place those two gloveboxes in much closer proximity, allowing them to be connected. However, as noted before, the size of the gloveboxes and process equipment are fixed for the purposes of this evaluation. Figure 8 shows an illustration of how an oxide fuel-production line might fit within the FCF Mockup Shop. 


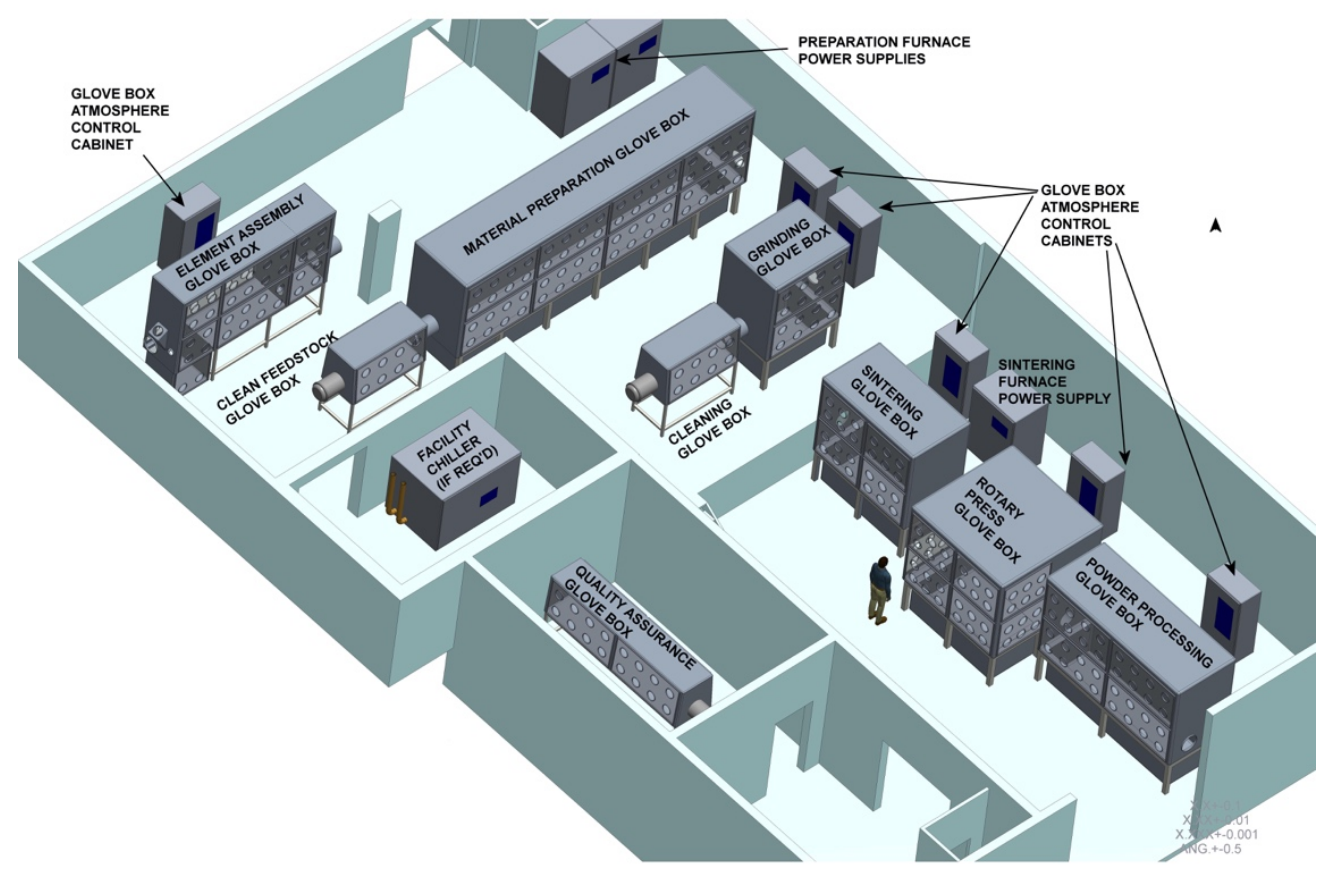

Figure 8. Ceramic/intermetallic fuel production line shown in the FCF Mockup Shop location.

\subsubsection{Metal Fuel Fabrication}

The metal-fuel production process follows the logic of Table 1. The space is large enough to accommodate two casting furnaces and two element assembly lines. If one element assembly line is sufficient, the additional space could be devoted to making larger, multiple element assemblies as may be needed by a particular reactor design. Figure 9 shows an illustration of how the casting fuel line would fit within the FCF Mockup Shop. 


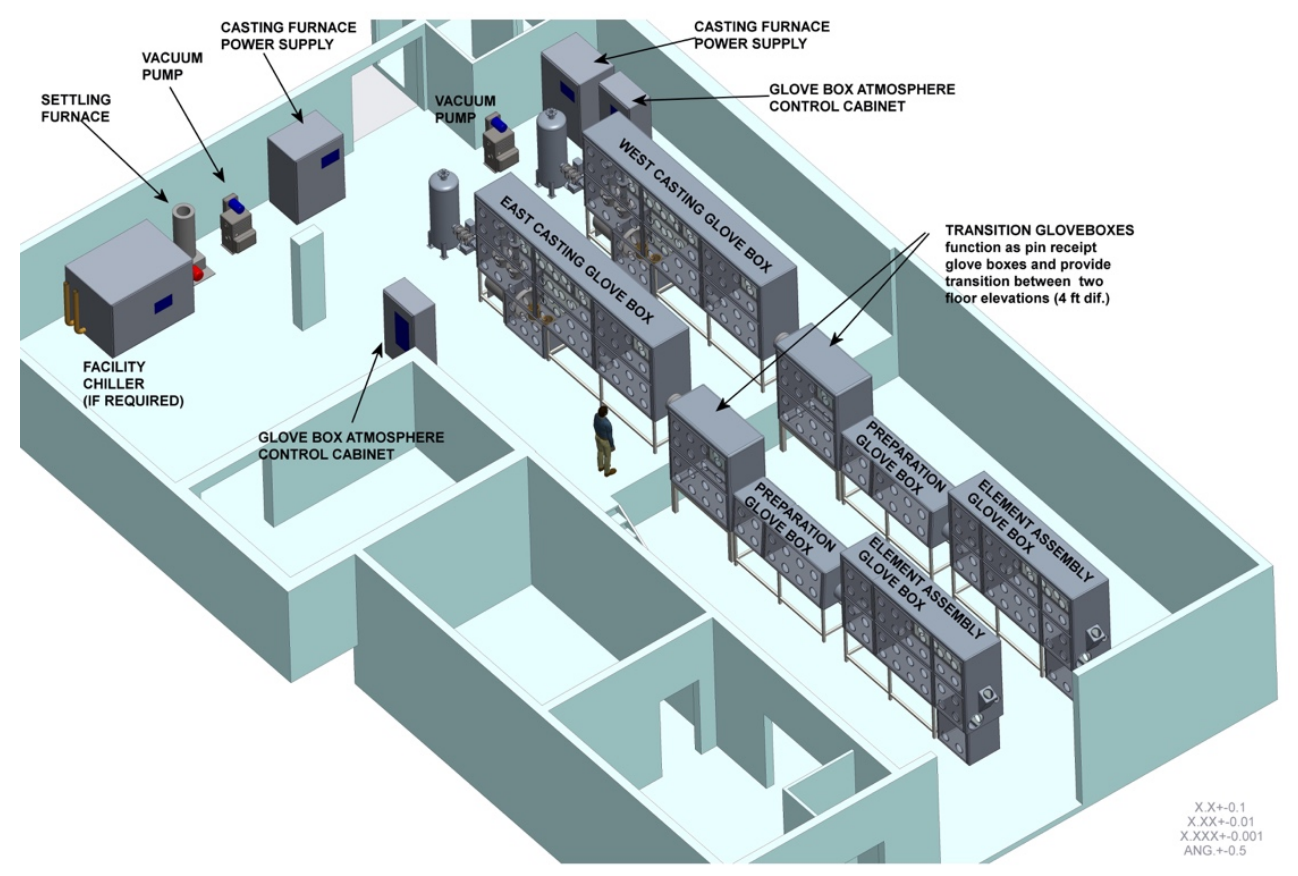

Figure 9. Metal fuel casting line shown in the FCF Mockup Shop. The two casting gloveboxes could be replaced by a metal-extrusion press as needed. The transition gloveboxes shown are in addition to the equipment listed in Table 1.

If a metal-extrusion press is needed, rather than casting furnaces, it and the associated ingot furnace could occupy the space allocated to the two casting gloveboxes. The overall length of the FCF Mockup Shop makes it amenable for extruding longer fuel sections, if needed $(10+\mathrm{ft}[3+\mathrm{m}])$. The elementassembly line could also be reconfigured to work with longer fuel extrusions, if needed.

\subsection{CPP-1634}

CPP-1634 is a high-bay building located in the INL INTEC area and is large enough to accommodate all the operations for oxide or metal fuel production on one level. No major modifications are required for this space, and it has sufficient height to accommodate the addition of a second floor (a mezzanine level) if necessary. CPP-1634 does not currently have a radiological ventilation system. However, the facility previously had an offgas stack and blowers, and installation of a new ventilation system specifically to support fuel manufacturing is feasible.

\subsubsection{Ceramic/Intermetallic Fuel Fabrication}

The ceramic/intermetallic fuel production process follows the logic shown in Table 3. Like the FCF Mockup Shop, all functions and operations can be located on one floor. With some rearrangement, the process can be configured into a contiguous $U$ shape, in which the process flows from one glovebox to the next. Figure 10 shows an illustration of how the oxide fuel production line might fit within CPP-1634. 


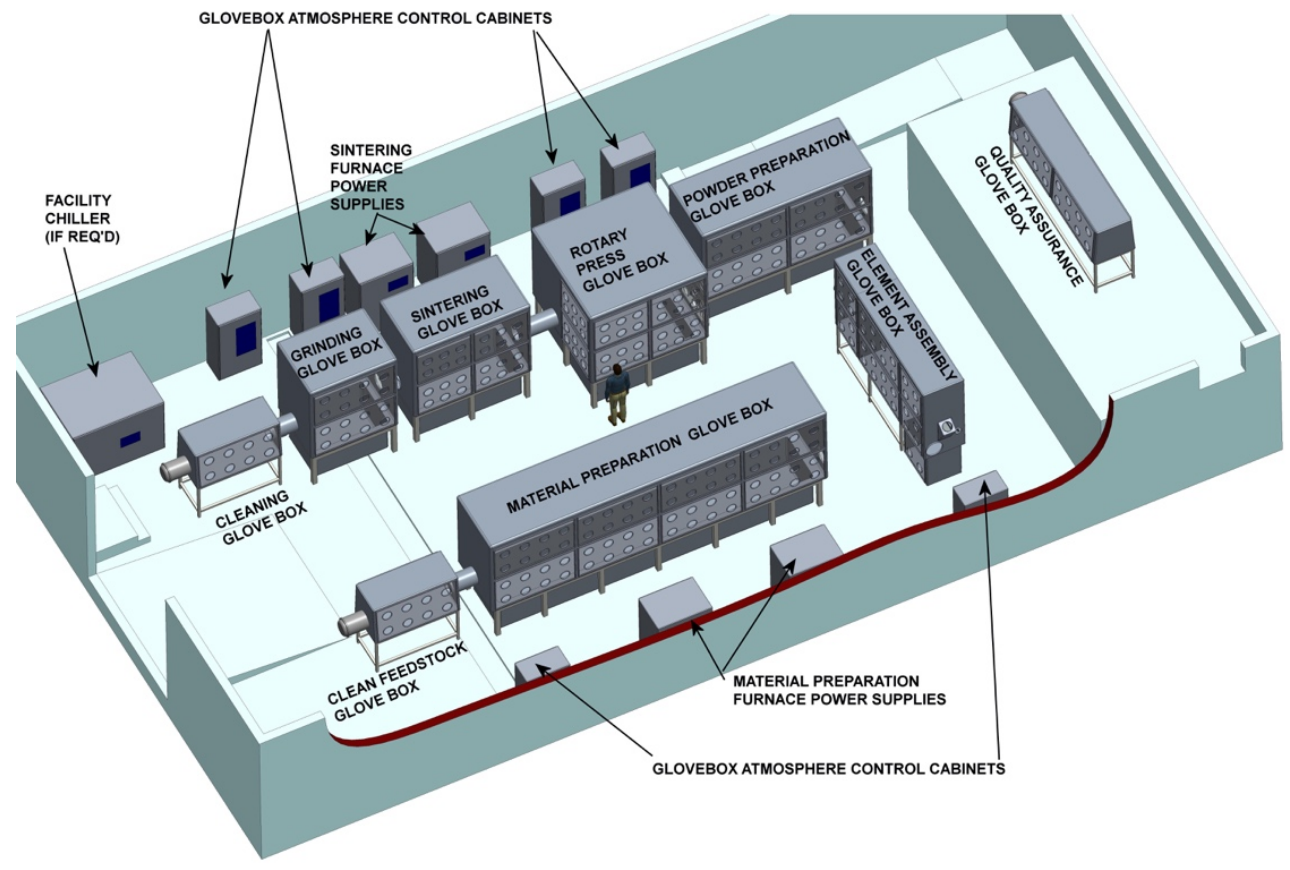

Figure 9. Ceramic/intermetallic fuel production line installed in CPP-1634.

\subsubsection{Metal Fuel Fabrication}

The metal-fuel production process follows the logic of Table 1. While all operations can be placed on one level, the single-floor space is large enough to support only one element assembly line. Installing a mezzanine level would expand that capacity. Likewise, a mezzanine would be needed to provide space for fabricating multiple element assemblies (as may be needed by some reactor designs). Figure 11 shows an illustration of how the casting fuel line would fit within CPP-1634.

If a metal-extrusion press is needed, rather than casting furnaces, it and the associated ingot furnace could occupy the space allocated the two casting gloveboxes. If the press can be placed at one end of the building, the process can be configured for longer extruded parts (i.e., greater than $10+\mathrm{ft} .[3+\mathrm{m}]$ ). The element-assembly gloveboxes could also be reconfigured to support working with longer fuel extrusions, if needed. 


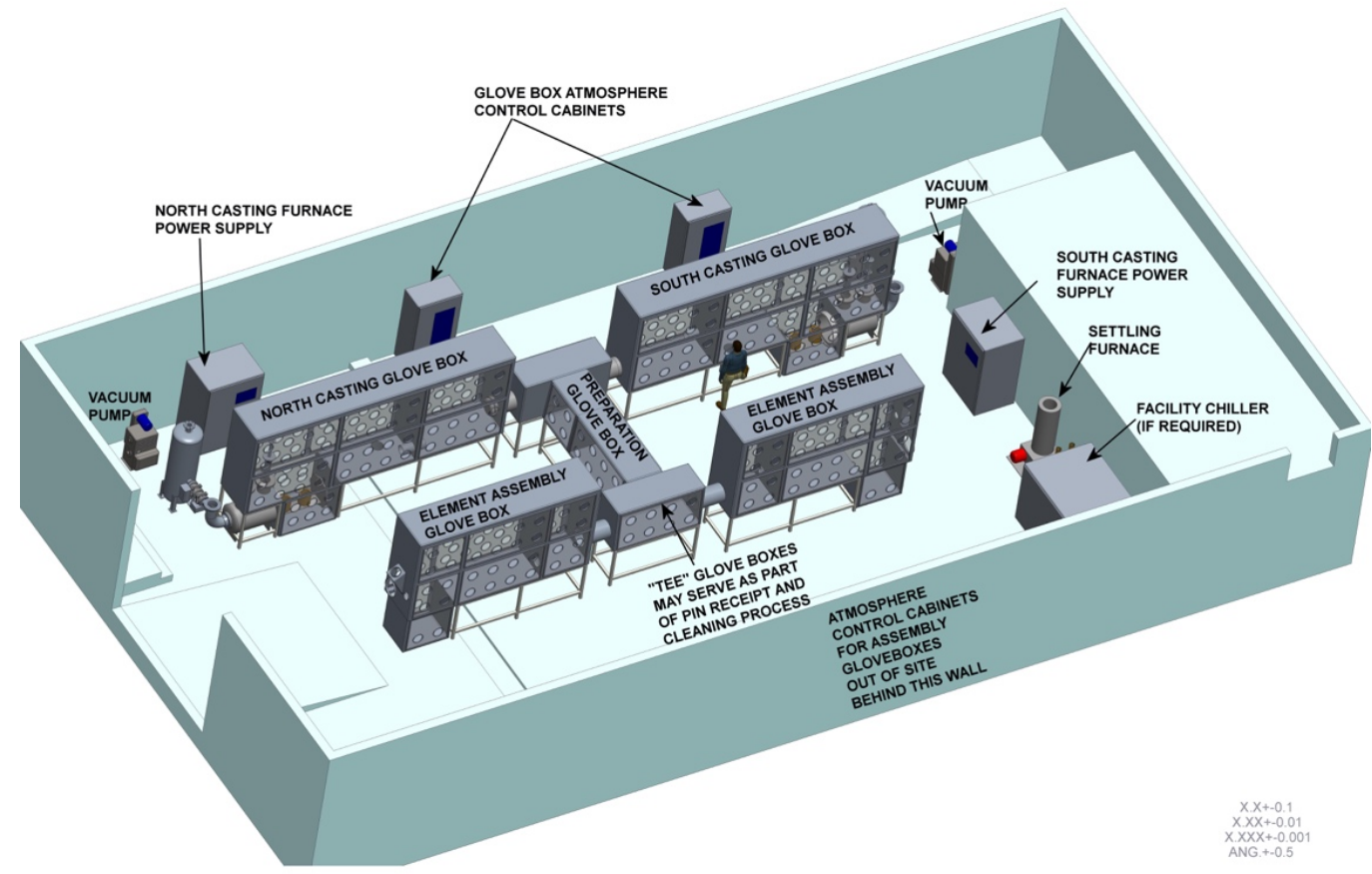

Figure 10. Metal-fuel casting line installed in the CPP-1634 building. 


\section{ROUGH ORDER OF MAGNITUDE COST ESTIMATES}

The tables in this section show the rough order of magnitude (ROM) costs $(-20 \% /+50 \%)$ for several aspects of the work and procurement needed to prepare fabrication lines for each of the three facilities. The values are based on recent experience and engineering judgment but are not formal estimates. As such, they are indicative of expected costs of repurposing existing buildings and installing fabrication lines, but are not definitive. Costs are estimated for preparing the buildings for installation of fabrication equipment (Table 4), design, building, and installation of gloveboxes and equipment (Tables 5 and 6), and operations through facility startup and annual production operation (Table 7). The following assumptions underlie these estimates, which should inform their application to further planning.

- Installation in building CPP-1634 is assumed as a reference (except for indications in Table 4) because very little work is needed to prepare that building for equipment installation: no reconfiguration, equipment removal or decontamination is necessary (although the current mission in the building needs to be relocated). So, cost estimates to prepare this building are less uncertain than for the other two buildings, for which some costs remain to be determined.

- The buildings will necessarily be authorized as HC-2 nuclear facilities, due to criticality-safety measures associated with the amount of ${ }^{235} \mathrm{U}$ in the HALEU in process. However, the radiological hazard of the material is assumed to be sufficiently low that building ventilation systems and gloveboxes are not classified as safety significant.

- Cost savings and synergies gained through acquisition of gloveboxes and fabrication equipment using a design/build/install contract is assumed.

- The ceramic/intermetallic fuel-fabrication equipment estimate is based on fabrication of intermetallic $\mathrm{U}_{3} \mathrm{Si}_{2}$ fuel, which is considered to bound the cost of equipment used to fabricate ceramic fuel such as $\mathrm{UO}_{2}$ or $\mathrm{UN}$.

- The metal-fuel-fabrication equipment estimate is based on fabrication of sodium-bonded metal alloy fuel rods similar to those used in EBR-II and the Fast Flux Test Facility.

- The operation of each fabrication line is assumed to require a dedicated crew of 20 full-time equivalents (FTEs) at a cost of \$7M per year (in 2019 dollars). Year-over-year cost estimates, as shown, are not escalated.

Table 4 indicates that the cost estimate for preparing Building CPP-1634 for installation of gloveboxes and process equipment begins at approximately $\$ 10 \mathrm{M}(-20 \% /+50 \%)$, as a lower bound, with additional costs associated with relocating the current mission from CPP-1634. Costs for preparing the MFC-765 FCF Mockup Shop and MFC-798 remain to be determined, with the cost of equipment removal and decontamination of MFC-798 and cost of relocating the FCF Mockup Shop mission (location TBD) currently unknown. Given these estimates, the total estimated cost of establishing engineering-scale HALEU fuel fabrication appears to begin at $\$ 43 \mathrm{M}$ to $\$ 48 \mathrm{M}(-20 \% /+50 \%)$, excluding cost of preparing existing buildings for new installation. Ongoing operating cost for a fabrication line is estimated at $\$ 7 \mathrm{M}$ per year (in 2019).

The cost estimates for the HALEU fuel-fabrication mission can be improved by further engineering evaluation to determine building preparation cost and through formal cost estimation for all identified costs using the INL cost-estimating process. 
Table 4. ROM cost estimates ( $-20 \% /+50 \%$ for values indicated) to prepare selected INL facilities for engineering-scale HALEU fuel fabrication (see Section 7 text for explanation).

\begin{tabular}{|l|c|c|c|}
\hline & $\begin{array}{c}\text { MFC-798 } \\
\text { (RLWTF) }\end{array}$ & $\begin{array}{c}\text { FCF Mockup } \\
\text { Shop }\end{array}$ & $\begin{array}{c}\text { CPP- } \\
\mathbf{1 6 3 4}\end{array}$ \\
\hline Cost to relocate current mission & 0 & TBD & $\$ 2 \mathrm{M}^{\mathrm{a}}$ \\
\hline $\begin{array}{l}\text { Facility decontamination and } \\
\text { decommissioning }\end{array}$ & TBD $^{\mathrm{b}}$ & 0 & 0 \\
\hline Building interior reconfiguration & TBD & TBD & 0 \\
\hline Utilities configuration & TBD & TBD & TBD \\
\hline Ventilation system & \$5.5M \\
\hline Life safety systems, rad and crit monitors & \multicolumn{3}{|c|}{$\$ 2 \mathrm{M}$} \\
\hline Liquid argon microbulk system & \multicolumn{3}{|c|}{$\$ 0.5 \mathrm{M}$} \\
\hline Chill water system & \multicolumn{2}{|c|}{$\$ 0.2 \mathrm{M}$} \\
\hline Data acquisition & \multicolumn{2}{|c|}{ TBD } \\
\hline Final fuel storage configuration & TBD & TBD & TBD \\
\hline Total to prepare for installation & \multicolumn{2}{|c|}{} \\
\hline
\end{tabular}

a. "Evaluation of MFC-736 for Radioisotope Power Systems Program Operations," INL TEV-3590, December 19, 2018.

b. TBD: to be determined; listed as such in this table to indicate specific aspects of building preparation that remain uncertain.

c. Assumes ventilation system is not safety class, but might be safety significant.

Table 5. Summary of ROM cost estimates $(-20 \% /+50 \%)$ for equipment design, procurement, and installation into INL facilities for engineering-scale HALEU fuel fabrication (see Section 7 text for explanation).

\begin{tabular}{|l|c|c|}
\hline & $\begin{array}{c}\text { Ceramic/Intermetallic } \\
\text { Line }\end{array}$ & Metal Line \\
\hline Equipment design $^{*}$ & $\$ 5 \mathrm{M}$ & $\$ 5 \mathrm{M}$ \\
\hline Gloveboxes $^{\mathrm{a}, \mathrm{b}}$ & $\$ 10 \mathrm{M}$ & $\$ 7.5 \mathrm{M}$ \\
\hline Seismic and safety analysis, permitting & $\$ 2 \mathrm{M}$ & $\$ 2 \mathrm{M}$ \\
\hline Equipment & $\$ 9 \mathrm{M}$ & $\$ 6 \mathrm{M}$ \\
\hline Installation and Test--out $^{\mathrm{a}}$ & $\$ 2 \mathrm{M}$ & $\$ 2 \mathrm{M}$ \\
\hline Total Equipment & $\$ 28 \mathrm{M}$ & $\$ 22.5 \mathrm{M}$ \\
\hline
\end{tabular}

a. Assumes acquisition using design/build/install contract to specification.

b. Assumes gloveboxes are not Safety Significant. 
Table 6. Detailed ROM cost estimates $(-20 \% /+50 \%)$ for equipment procurement for engineering-scale HALEU fuel fabrication (see Section 7 text for explanation).

\begin{tabular}{|c|c|}
\hline Ceramic/Intermetallic Fuel Line & \\
\hline Clean feedstock glovebox & $\$ 0.2 \mathrm{M}$ \\
\hline Material preparation glovebox & $\$ 2 \mathrm{M}$ \\
\hline Powder preparation glovebox & \multirow{3}{*}{$\$ 5 \mathrm{M}$} \\
\hline Rotary press glovebox & \\
\hline Sintering glovebox & \\
\hline Grinding glovebox & $\$ 0.5 \mathrm{M}$ \\
\hline Cleaning glovebox & $\$ 0.2 \mathrm{M}$ \\
\hline Element assembly glovebox & $\$ 1 \mathrm{M}$ \\
\hline QA glovebox & $\$ 1 \mathrm{M}$ \\
\hline Ceramic/Intermetallic Fuel Line Gloveboxes ${ }^{a}$ & $\$ 10 M$ \\
\hline Weight balance, feedstock cleaning station & $\$ 0.25 \mathrm{M}$ \\
\hline Controlled-atmosphere furnace (arc melter, U3Si2 basis) & $\$ 1 \mathrm{M}$ \\
\hline Rough powder prep station & $\$ 0.5 \mathrm{M}$ \\
\hline 2 weight balances, powder characterization @ \$250k ea. & $\$ 0.5 \mathrm{M}$ \\
\hline 3 canning/transfer stations @ 100k ea. & $\$ 0.3 \mathrm{M}$ \\
\hline Ball Mill and powder granulator & $\$ 1 \mathrm{M}$ \\
\hline Rotary press & $\$ 2 \mathrm{M}$ \\
\hline 2 weight balances and pellet metrology equipment & $\$ 0.3 \mathrm{M}$ \\
\hline 2 controlled-atmosphere sintering furnaces @ \$1.5M ea. & $\$ 3 \mathrm{M}$ \\
\hline Centerless grinder & $\$ 0.4 \mathrm{M}$ \\
\hline Ultrasonic cleaners and pellet dryer & $\$ 0.2 \mathrm{M}$ \\
\hline Pellet QA/QC equipment & $\$ 0.1 \mathrm{M}$ \\
\hline Welder and welding station & $\$ 0.5 \mathrm{M}$ \\
\hline Helium leak checker & $\$ 0.1 \mathrm{M}$ \\
\hline Ceramic/Intermetallic Fuel Line Equipment & $\$ 10 M$ \\
\hline \multicolumn{2}{|l|}{ Metal Fuel Line } \\
\hline 2 casting gloveboxes @\$2M EA. & $\$ 4 \mathrm{M}$ \\
\hline 2 preparation gloveboxes@ @ $\$ 0.75 \mathrm{M}$ ea. & $\$ 1.5 \mathrm{M}$ \\
\hline 2 element assembly gloveboxes @ \$1M ea. & $\$ 2 \mathrm{M}$ \\
\hline Metal Fuel Line Gloveboxes $^{\mathbf{a}}$ & $\$ 7.5 \mathrm{M}$ \\
\hline Weight balance, feedstock cleaning station & $\$ 0.25 \mathrm{M}$ \\
\hline 2 injection casting furnaces $@ \$ 2 \mathrm{M}$ ea. & $\$ 4 \mathrm{M}$ \\
\hline 2 canning/transfer stations@100k ea. & $\$ 0.2 \mathrm{M}$ \\
\hline 2 mold removal devices @ \$0.1M & $\$ 0.2 \mathrm{M}$ \\
\hline 2 fuel slug inspection stations $@ \$ 0.2 \mathrm{M}$ ea. & $\$ 0.4 \mathrm{M}$ \\
\hline 2 fuel slug trimming devices @ \$0.1 ea. & $\$ 0.2 \mathrm{M}$ \\
\hline Fuel slug final inspection and Na prep stations & $\$ 0.1 \mathrm{M}$ \\
\hline Welder and welding station & $\$ 0.5 \mathrm{M}$ \\
\hline Helium leak checker & $\$ 0.1 \mathrm{M}$ \\
\hline Wire wrap machine & $\$ 0.1 \mathrm{M}$ \\
\hline Metal Fuel Line Equipment & $\$ 6 M$ \\
\hline
\end{tabular}


Table 7. ROM cost estimates (with notional schedule) for operations to startup and implement engineering-scale HALEU fuel fabrication (see Section 7 text for explanation).

\begin{tabular}{|c|c|c|c|c|}
\hline \multicolumn{5}{|c|}{ Basis: full operating crew of 20 people at $\$ 7 \mathrm{M} / \mathrm{yr}$, in non-escalated 2019 dollars } \\
\hline & year 1 & year 2 & year 3 & year $4+$ \\
\hline $\begin{array}{l}\text { Design/build/install contract specification and } \\
\text { support, } 2 \text { FTEs } 18 \mathrm{mos}\end{array}$ & $\$ 0.7 \mathrm{M}$ & $\$ 0.35 \mathrm{M}$ & - & - \\
\hline Operations preparation, 10 FTEs 6 FTEs 6 mos & - & $\$ 1.75 \mathrm{M}$ & - & - \\
\hline $\begin{array}{l}\text { Equipment acceptance and systems operations testing, } \\
20 \text { FTEs } 6 \text { mos }\end{array}$ & - & $\$ 3.5 \mathrm{M}$ & - & - \\
\hline Readiness prep, 20 FTEs 6 mos & - & - & $\$ 3.5 \mathrm{M}$ & - \\
\hline Readiness assessment and review, 20 FTEs 6 mos & - & - & $\$ 3.5 \mathrm{M}$ & - \\
\hline Operations & - & - & - & $\$ 7 \mathrm{M}$ \\
\hline Total & $\$ 0.7 \mathrm{M}$ & $\$ 5.6 \mathrm{M}$ & $\$ 7 \mathrm{M}$ & $\$ 7 \mathrm{M}$ \\
\hline
\end{tabular}

\section{CONCLUSION}

As a result of this study, the following can be concluded:

- Three buildings at INL are suitable for housing engineering-scale HALEU fuel fabrication, each apparently capable of accommodating the maximum throughput rate envisioned (i.e., $2.5 \mathrm{MTHM} / \mathrm{yr}$ ).

- Generic fuel-fabrication process descriptions provide sufficient detail to support preconceptual fuel-fabrication facility layouts in the selected buildings.

- ROM estimates of cost for preparing generic fuel-fabrication lines (i.e., without consideration of fuel-design-specific process equipment or fixturing) begin at $\$ 43 \mathrm{M}$ to $\$ 48 \mathrm{M}(-20 \% /+50 \%)$, with costs of preparing specific buildings yet to be determined.

\section{REFERENCES}

1 John Milko and Todd Allen, “The Global Race for Advanced Nuclear," Third Way, May 18, 2017, available at https://www.thirdway.org/infographic/the-global-race-for-advanced-nuclear.

2 Exploring the Role of Advanced Nuclear in Future Energy Markets: Economic Drivers, Barriers, and Impacts in the United States. EPRI, Palo Alto, CA: 2018. 3002011803.

3 Maria Korsnick, President and CEO Nuclear Energy Institute, to The Honorable Rick Perry, Secretary of Energy, U.S. DOE, "Need for High Assay Low Enriched Uranium,” July 5, 2018.

4 DOE Standard DOE-STD-1194-2011, “Nuclear Material Control and Accountability,” June 2011.

5 Arthur Y. Flores, "Hazard Categorization for CPP-1634 at the Material Security and Consolidation Complex,” ECAR-999, Idaho National Laboratory, Rev. 0, August 6, 2010. 